\title{
Systematic Review \\ TERT Promoter Alterations in Glioblastoma: A Systematic Review
}

\author{
Nathalie Olympios ${ }^{1}\left(\mathbb{D}\right.$, Vianney Gilard ${ }^{2}$, Florent Marguet ${ }^{3}\left(\mathbb{D}\right.$, Florian Clatot ${ }^{1,4}$, Frédéric Di Fiore ${ }^{1,4,5}$ \\ and Maxime Fontanilles $1,4, *$
}

1 Cancer Centre Henri Becquerel, Department of Medical Oncology, Rue d'Amiens, 76000 Rouen, France; Nathalie.olympios@chb.unicancer.fr (N.O.); florian.clatot@chb.unicancer.fr (F.C.); Frederic.difiore@chu-rouen.fr (F.D.F.)

2 Neurosurgery Department, Rouen University Hospital, 1 rue de Germont, 76000 Rouen, France; Vianney.gilard@chu-rouen.fr

3 Department of Pathology, INSERM U1245, Normandie Univ, UNIROUEN and Rouen University Hospital, Normandy Centre for Genomic and Personalized Medicine, 76000 Rouen, France; florent.marguet@chu-rouen.fr

4 Inserm U1245, Normandie Univ, UNIROUEN, IRON Group, Normandy Centre for Genomic and Personalized Medicine, 76000 Rouen, France

5 Department of Digestive Oncology, Rouen University Hospital, 1 rue de Germont, 76000 Rouen, France

* Correspondence: maxime.fontanilles@chb.unicancer.fr; Tel.: +33-23-208-2239

Citation: Olympios, N.; Gilard, V.; Marguet, F.; Clatot, F.; Di Fiore, F.; Fontanilles, M. TERT Promoter Alterations in Glioblastoma: A Systematic Review. Cancers 2021, 13, 1147. https://doi.org/10.3390/ cancers13051147

Academic Editor: Pierre A. Robe

Received: 22 December 2020

Accepted: 3 March 2021

Published: 8 March 2021

Publisher's Note: MDPI stays neutral with regard to jurisdictional claims in published maps and institutional affiliations.

Copyright: () 2021 by the authors. Licensee MDPI, Basel, Switzerland. This article is an open access article distributed under the terms and conditions of the Creative Commons Attribution (CC BY) license (https:// creativecommons.org/licenses/by/ $4.0 /)$.
Simple Summary: Glioblastoma is the most common malignant primary brain tumor in adults. Glioblastoma accounts for 2 to 3 cases per 100,000 persons in North America and Europe. Glioblastoma classification is now based on histopathological and molecular features including isocitrate dehydrogenase (IDH) mutations. At the end of the 2000s, genome-wide sequencing of glioblastoma identified recurrent somatic genetic alterations involved in oncogenesis. Among them, the alterations in the promoter region of the telomerase reverse transcriptase (TERTp) gene are highly recurrent and occur in $70 \%$ to $80 \%$ of all glioblastomas, including glioblastoma IDH wild type and glioblastoma IDH mutated. This review focuses on recent advances related to physiopathological mechanisms, diagnosis, and clinical implications.

\begin{abstract}
Glioblastoma, the most frequent and aggressive primary malignant tumor, often presents with alterations in the telomerase reverse transcriptase promoter. Telomerase is responsible for the maintenance of telomere length to avoid cell death. Telomere lengthening is required for cancer cell survival and has led to the investigation of telomerase activity as a potential mechanism that enables cancer growth. The aim of this systematic review is to provide an overview of the available data concerning TERT alterations and glioblastoma in terms of incidence, physiopathological understanding, and potential therapeutic implications.
\end{abstract}

Keywords: glioblastoma; TERT; telomerase inhibition

\section{Introduction}

Glioblastoma is the most frequent and the most aggressive primary brain malignancy [1,2]. Glioblastoma is classified as grade IV glioma according to the WHO 2016 classification, which is the highest grade in the classification of gliomas. The standard of care for glioblastoma has not substantially changed in the past decade [3] and prognosis remains poor, with a median survival of approximately 15 months [4]. This is despite aggressive multimodal treatment combining surgical resection (when feasible), radiotherapy, and chemotherapy, which has a highly negative impact on the quality of life [5]. Glioblastoma was the first cancer to be studied by The Cancer Genome Atlas (TCGA), which aims to catalog and discover somatic genomic alterations in large cohorts of human tumors through integrated multidimensional analyses [6]. Molecular alterations mainly regarding EGFR, 
ATRX, IDH1/2, TP53, ERBB2, NF1, PI3KR1, and MGMT have been explored, paving the way for a new molecular era in neuro-oncology. Since these initial explorations, a variety of genetic and epigenetic alterations have been identified in glioblastoma [6-8] in an attempt to increase the molecular understanding of high-grade glioma pathogenesis and thus to personalize treatments to improve outcomes. Integrated genotypic and phenotypic data classifying central nervous system (CNS) tumors are now integrated in the 2016 updated WHO classification [9] to improve diagnosis. The 2016 classification distinguishes three categories of glioblastoma: non-mutated IDH glioblastomas, mutated IDH glioblastoma, and glioblastoma Not Otherwise Specified (NOS). Nevertheless, current findings have not yet led to subsequent changes in treatment modalities.

Among the potential drivers of interest, alterations in the TElomerase Reverse Transcriptase promoter (TERTp) have been reported in up to $80 \%$ of glioblastomas [10]. Telomeres are nucleoprotein complexes located at the end of chromosomes and are required for chromosomal integrity. Telomeres shorten at every cell cycle, eventually leading to cell death or senescence [11]. Telomerase is responsible for the repair of telomeres to maintain their length and avoid cell death. Telomere lengthening is required to achieve the infinite proliferation of cancer cells; thus, telomerase activity has been investigated as a potential mechanism for cancer growth [10]. Mutations in TERTp, the promoter region of TERT gene, were initially described in up to $70 \%$ melanoma tumors [12,13]. These mutations were then further explored in other tumors, including glioblastoma and additional emerging tumor research areas, such as hepatocellular carcinoma and urothelial carcinoma [10]. More precisely, mutations occur at two mutually exclusive hotspots located $-124 \mathrm{bp}$ and $-146 \mathrm{bp}$ upstream of the TERT translation start site: chromosome 5p15.33: 1,295,228 C > T and 1,295,250 C > T, referred to as C228T and C250T, respectively [14]. These mutations are well-described alterations and result in the upregulation of TERT expression required for telomerase activation [15].

The objective of this systematic review was to give an overview of available data concerning TERTp -124 and -146 alterations and glioblastoma in terms of incidence, physiopathological understanding, and potential therapeutic implications. Most of the present review will primarily focus on the two most common types of glioblastoma: "classical" non-mutated IDH glioblastoma as well as mutated IDH glioblastoma. A brief update will be also made on glioblastoma occurring in children and on rare histological subtypes of non-mutated IDH glioblastomas in adults.

\section{Materials and Methods}

A literature search was carried out to identify the relevant studies published since 2012. PubMed was searched for published articles, and clinicaltrials.gov (accessed on 20 December 2020) was searched for previous and ongoing clinical trials. Research terms included «glioblastoma», «glioma», «brain tumor» associated with «TERT», «telomeres», «telomerase», and «genomic landscape». The selected published studies included only original research papers; reviews were excluded. Additional relevant articles were identified from the reference list of articles identified in the initial search. This systematic review followed the Prisma statement.

\section{Results and Discussion}

\subsection{Flow-Chart}

Overall, ninety-two studies were selected for the present review out of 586 pre-selected articles, Figure 1. 


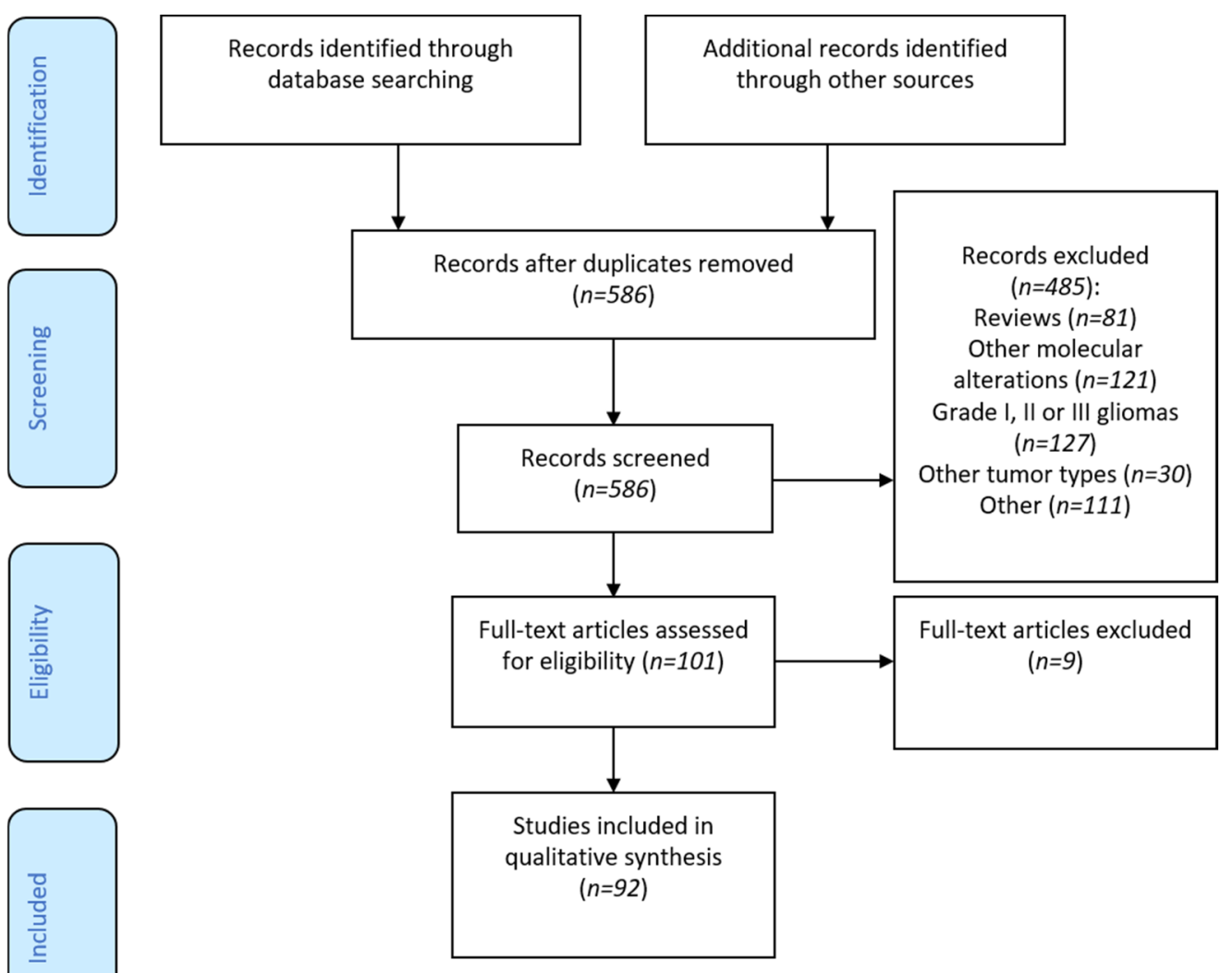

Figure 1. Flow-chart.

\subsection{TERT Genomic Alterations in Glioblastoma}

\subsubsection{Incidence}

A comprehensive analysis of a TCGA data set found that among 6835 cancers, $73 \%$ expressed TERT. The TERT-expressing cancers were associated with TERTp mutations and with other point mutations, genomic rearrangements, DNA amplifications, or transcript fusions, and these alterations could predict telomerase activity [16]. Overall, TERTp mutations are the most frequent cancer genomic alterations. TERTp mutations occur in $51 \%$ of all glioma grades. Regarding glioblastoma, mutations commonly occur at two hotspots, referred to as C228T and C250T, which are mutually exclusive and occur in $80-90 \%$ of glioblastoma patients [10,17-20]. Such tumors most frequently have a frontal [21] or temporal location [22] and occur more frequently in older patients compared to IDH-mutated (IDH-mut) glioblastoma. Recently, two other TERTp gain-of-function alterations were described: TERTp c.1-100_1-79dup and TERTp c.1-110_1-89. These newly-described alterations occur in less than $1 \%$ of glioblastoma $I D H$-wild type $(I D H$-wt) and were not integrated into our systematic review [23].

\subsubsection{Diagnosis}

The gold standard to identify TERTp mutations in glioblastoma remains based on molecular characterization of tumor DNA. The identification of TERTp mutations traditionally relied on Sanger sequencing, based on tumor DNA sequencing. Tumor heterogeneity or the scarcity of tumor DNA due to difficulties in tumor collection may lead to a lack of sensitivity of this historical technique [24-27]. Alternative sequencing methods were recently developed to increase the mutation detection rate in cases of low mutant allele frequency (MAF); these methods include Droplet Digital PCR (ddPCR), mass-spectrometrybased tests [28], and next-generation sequencing (NGS). ddPCR techniques have a higher sensitivity than Sanger sequencing in the detection of IDH1 and TERTp mutations in glioma [29-31]. NGS assays also offer the possibility of deep detection and multiplexing 
the search for genomic alterations [32-36]. Euskirchen et al. [37] described a pocket-size nanopore sequencing device that could provide same-day detection of structural variants, point mutations, and methylation profiling. In contrast to the NGS assay, ddPCR-based TERTp mutation detection requires a lower tumor DNA quantity, and it might be useful in the peritumoral characterization of brain tumors [38]. Barritault et al. [39] applied molecular testing to 28 initially nondiagnostic biopsies of gliomas and were able to reclassify 6 of them after assessing for IDH and TERTp mutation status via SNaPshot PCR. The diagnostic performances of the different methods are summarized in Table 1.

Table 1. Diagnostic performances of the different methods to detect TERTp mutations.

\begin{tabular}{|c|c|c|c|c|}
\hline Method & Population (Number of Patients) & Reference Method & Accuracy & Reference \\
\hline \multicolumn{5}{|c|}{ Molecular biology techniques on the tumor } \\
\hline NGS targeted panel & 18 glioblastomas & - & 7 TERTp mut/18 (38.9\%) & [32] \\
\hline NGS targeted panel & 47 glioblastomas & Sanger sequencing & $\begin{array}{c}30 \text { TERTp mut/47 (64\%) } \\
\text { Se } 99 \% \text {, Spe } 100 \%\end{array}$ & [34] \\
\hline NGS targeted panel & 121 gliomas & Sanger sequencing & $\begin{array}{l}66 \text { TERTp mut } / 121 \\
\text { Se } 100 \% \text {, Spe } 100 \%\end{array}$ & [36] \\
\hline Nanopore & 16 glioblastomas & NGS & Se $100 \%$, Spe $60 \%$ & [37] \\
\hline Droplet digital PCR & 52 grade IV gliomas & Sanger sequencing & Se $100 \%$, Spe $100 \%$ & [31] \\
\hline \multicolumn{5}{|c|}{ Molecular biology techniques on the periphery of the tumor } \\
\hline Snapshot & 22 gliomas & NGS & Se $87.5 \%$, Spe $100 \%$ & [39] \\
\hline \multicolumn{5}{|c|}{ MRI parameters } \\
\hline Support Vector Machine & 112 gliomas & Tumor sequencing & Se $85.7 \%$, Spe $54.8 \%$ & {$[40]$} \\
\hline Spectroscopy & 112 gliomas & Tumor sequencing & Se $83.3 \%$, Spe $95.2 \%$ & [41] \\
\hline $\begin{array}{l}\text { Dynamic susceptibility } \\
\text { contrast- and dynamic } \\
\text { contrast-enhanced- MRI }\end{array}$ & 60 gliomas & Tumor sequencing & $\begin{array}{l}\text { Se } 56-84 \%, \text { Spe } \\
53.6 \%-83.3 \%\end{array}$ & [42] \\
\hline
\end{tabular}

The non- or minimally invasive detection of TERTp mutations is challenging in glioblastoma patients. It is desirable to increase diagnostic accuracy while limiting invasive procedures, especially for older patients and/or patients with a poor general condition. In this setting, the liquid biopsy concept has emerged in neuro-oncology. The concept of liquid biopsy is based on the molecular characterization of freely circulating tumor fragments that are found in easily accessible fluids such as plasma or cerebrospinal fluid (CSF).

Among these fragments, circulating tumor DNA is the most described in the literature and can be used to detect TERTp mutations by ddPCR or NGS-based sequencing methods [29-36,43]. ddPCR allows for significant sequencing depth and is thus suitable for the detection of a small quantity of circulating tumor DNA as observed in the plasma of patients suffering from glioma. The proportion of patients with a mutation detected in plasma is less than $10 \%$; on the other hand, the specificity is $100 \%$ [31,44]. The low detection rate of TERTp mutations in plasma could be due to the size of the DNA fragments. These are shorter in patients with glioma and therefore may negatively influence the accuracy test of ddPCR by amplicon mismatch [45]. The plasma detection of TERTp mutations is an important issue for improving the management of patients with glioblastoma. Data on large prospective cohorts are still lacking, possibly linked to a limitation of current sequencing techniques.

The application of magnetic resonance imaging to diagnose glioblastoma and characterize the TERTp (wild type vs. mutated) status is also a noninvasive and promising technique [40-42,46-48]. In a recent study of 43 patients, Zhang et al. [42] showed that dynamic contrast-enhanced (DCE)-magnetic resonance imaging (MRI) histogram preoperative analyses demonstrate good analytical performance for the identification of $I D H$, 
MGMT, and TERTp alterations [42]. DCE-MRI provides qualitative and quantitative information on tumor perfusion. The mean ratio between the extravascular extracellular space and blood plasma, also called Kep, distinguished TERTp-mutated (TERTp-mut) glioma from TERTp-wild type (TERTp-wt) glioma with a sensitivity of 0.76 and a specificity of 0.78 . Confirmatory and larger cohorts are now required to confirm the reproducibility of the results in order to generalize its use in daily practice. Invasive and non-invasive procedures to detect TERTp mutations are summarized in Figure 2.

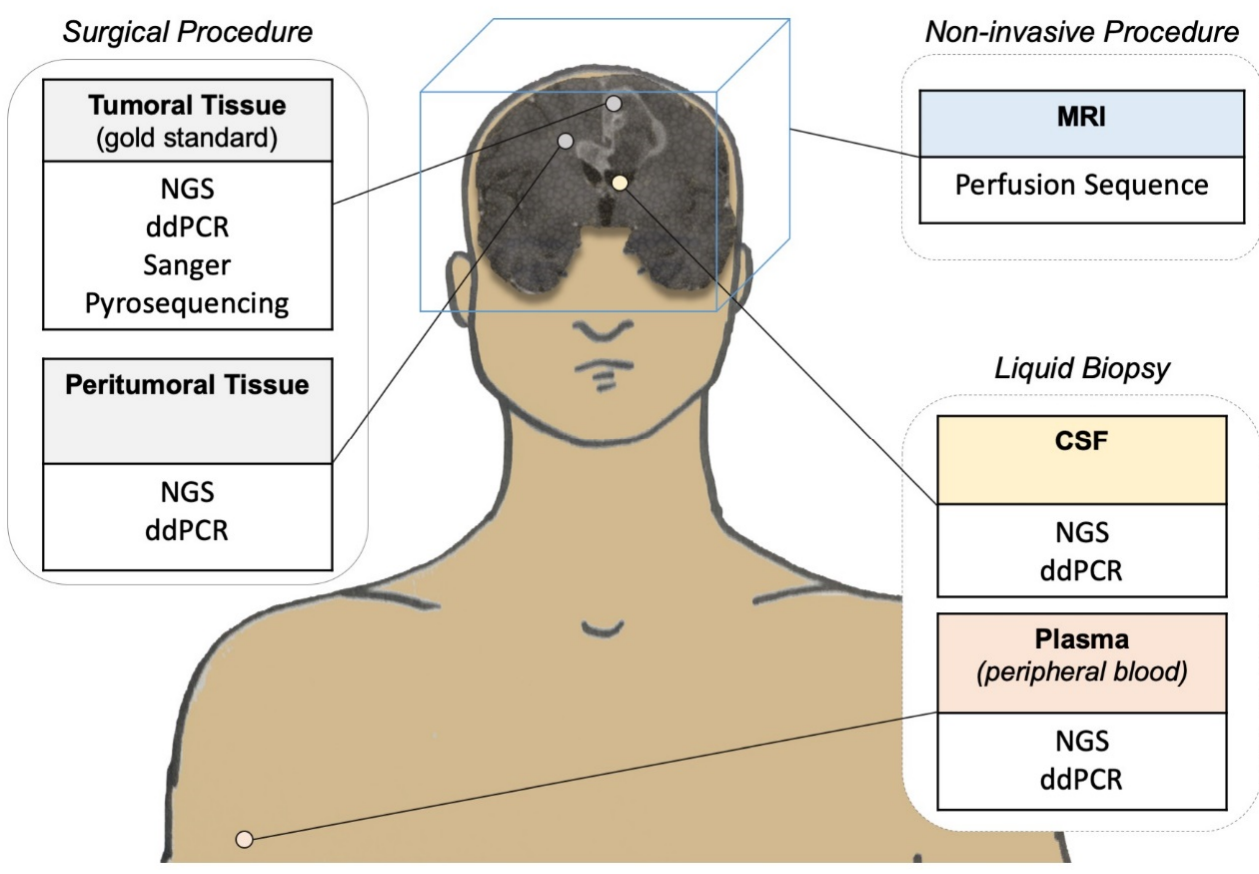

Figure 2. Methods to detect TERTp alterations in patients with glioblastoma. The current reference method is the detection of alterations based on sequencing techniques applied to tumor tissue obtained from either lesion resection or from targeted biopsy in cases of non-resectable tumors. The other methods, particularly noninvasive or minimally invasive methods, are still under development and are not yet used in routine clinical practice.

\subsection{Physiopathology}

\subsubsection{Telomerase Activity: Overcoming Replicative Senescence}

The limitless multiplication of cancer cells is a fundamental feature of cancer growth. Telomeres, which compose the terminal ends of each chromosome, are repetitive DNA sequences that protect chromosome ends from being recognized as double-strand breaks and therefore be destroyed by the DNA damage response system [49]. Telomeres shorten at every cycle, eventually leading to cell death.

To overcome this mechanism, cells can activate telomere-maintenance mechanisms such as telomerase activation [50]. Telomerase is a ribonucleoprotein that consists of an RNA subunit and a reverse transcriptase catalytic subunit, which adds telomeric repeat sequences of nucleic acids to chromosome ends, thereby maintaining telomere length [51]. Arita et al. [51] confirmed the somatic origin of TERTp mutations by sequencing 546 tumor samples and matched normal DNA from peripheral white blood cells in selected cases. Mutations in the TERTp region resulted in an ETS (E26 transformation-specific family transcription factor) binding site recognized by GABPA, a component of the multimeric transcription factor GABP, which facilitates reactivation of telomerase [52]. TERTp mutations activate TERT mRNA expression through the creation of a de novo ETS transcription factor-binding site $[12,53]$. The TERT expression level in tumors carrying TERTp mutations was found to be 6.1 times higher on average than that of wild-type tumors, indicating that the mutated promoter leads to TERT upregulation [51]. This finding was confirmed in 
further studies [7,53], suggesting that TERT expression represents a specific and sensitive surrogate for the presence of TERTp mutations.

$\alpha$-thalassemia/mental retardation syndrome X-linked (ATRX) is an X-linked gene of the SWI/SNF family, mutations in which cause syndromal mental retardation and downregulation of a-globin expression [54]. ATRX and DAXX (death-associated protein 6) are central components of a chromatin-remodeling complex required for the incorporation of H3.3 histone proteins into the telomeric regions of chromosomes [55]. Dysfunction of the ATRX/DAXX complex is known to result in alternative lengthening of telomeres along with more widespread genomic destabilization. Interestingly, there is a significant inverse relationship between loss-of-function mutations in ATRX and TERTp in gliomas [51]. ATRX-mutated glioblastoma does not exhibit elevated TERT RNA expression compared to TERTp-mutated glioblastoma [7]. Alternatively, tumors without telomerase activity may acquire telomere lengthening by a homologous recombination-mediated mechanism known as alternative lengthening of telomeres (ALT). This suggests that TERTp mutations and alternative lengthening of telomeres secondary to ATRX mutations serve as complementary mechanisms for telomere lengthening and are an essential step in glioblastoma oncogenesis.

Whether TERTp mutations constitute an early or late event in glioblastoma genesis is yet not fully elucidated. Despite elevated TERT expression, TERTp-mutated tumors have shorter telomeres $[16,53,56]$ than matched control samples, suggesting that these mutations may constitute a late event in oncogenesis when telomeres are exhausted. However, Abou et al. [57] suggested that glioblastoma develops early on from a common precursor with the loss of at least one gene copy (heterozygous deletion) of PTEN along with a TERTp mutation; this suggestion was based on their high frequency and their shared occurrence in different tumor foci from the same patient. A comparison of peritumoral tissue (subventricular zone), tumor tissue, and matched normal tissue found that the peritumoral area already harbored TERTp mutations and could be the origin of the tumor [58]. Korber et al. [59] suggested both a distant origin of de novo glioblastoma, up to seven years before diagnosis, and a common path of oncogenesis, with early occurrence of one or more chromosome rearrangements, such as 7 gain, $9 p$ loss, or 10 loss. In this oncogenesis model, TERTp mutation occurs later, during the rapid growth of the glioblastoma.

Overall, the maintenance of telomere length via telomerase activity resulting from $T E R T p$ mutations appears to be an important event in gliomagenesis. The clinical impact of TERTp alterations, whether prognostic or therapeutic, is discussed later in this review.

\subsubsection{Association of TERTp Mutations and Other Molecular Alterations}

The molecular characterization of glioblastoma has led to the identification of different prognostic glioblastoma subgroups based on the presence of IDH hotspot mutations, a wellestablished molecular feature of gliomas [60]; TERTp mutation and MGMTp methylation are also used for subgrouping. The classification of glioblastoma is now based on IDH status. The WHO 2016 classification distinguishes three entities: glioblastoma IDH-wt, glioblastoma IDH-mut, and glioblastoma Not Otherwise Specified-NOS. Glioblastoma NOS present with astrocytic features and anaplasia, microvascular proliferation, and/or necrosis but with unavailable IDH mutational status. TERTp mutations [9,17,61,62], EGFR alterations [24,63], and MGMTp methylation [14,21,64-66] are also integrated in daily practice. The majority of glioblastomas are IDH-wt; a combination of TERTp mutation and IDH-wt is the most common genotype observed in glioblastoma [14]. The differences in the biological processes involved in the telomerase pathway remain unclear between $I D H$-wt and $I D H$-mut glioblastomas. In comparison, a transcriptomic study carried out on samples of lower-grade gliomas did not make it possible to identify any differences between the IDH-mut/TERTp-wt and IDH-mut/TERTp-mut groups [67]. Beyond IDH and TERTp-mut glioblastoma, Diplas et al. [29] described a rare molecular subgroup of diffuse gliomas defined by the absence of common biomarkers (IDH1/2, codeletion 1p19q, TERTp mutations) and characterized by SMARCAL1 inactivating mutations. SMARCAL1 plays a role as a novel genetic mechanism of ALT and is involved in a novel mechanism 
of telomerase activation in glioblastomas that occurs via chromosomal rearrangement upstream of TERT. Integrating TERTp mutations into the landscape of molecular alterations in glioblastoma and clarifying the relationships among the known alterations could increase the molecular understanding of high-grade gliomas pathogenesis.

\subsubsection{TERTp Mutation Status: An Independent Prognostic Factor?}

Whether TERTp mutation status is an independent prognostic factor is highly controversial. Numerous studies have highlighted the potential negative independent prognostic impact of TERTp mutations [18-21,24,25,61,62,68-74], whereas others $[14,17,51,53,56,63-$ $65,75,76]$ have suggested that the deleterious impact of TERTp mutation is correlated to the presence of cofounding molecular and clinical factors such as older age, IDH-wt status, and unmethylated MGMTp status. The MGMT gene codes for a protein involved in the DNA repair system. Its role is in particular to demethylate DNA, especially after alkylating agent exposition. Methylation of its promoter, and therefore gene silencing, occurs in approximately $45 \%$ of glioblastoma and is a favorable prognostic factor upon exposure to temozolomide. However, in adults suffering from glioblastoma, the presence of the methylation of the MGMT promoter does not currently constitute a biomarker necessary for the administration of temozolomide since temozolomide remains effective in overall survival in both methylated and unmethylated MGMTp glioblastomas. [66].

In a study of 473 adult gliomas among which 240 glioblastomas, Killela [62] studied both IDH and TERTp mutations and found that TERTp mutations in glioblastomas predicted poor survival even in tumors without an IDH mutation. Patients harboring TERTp-mut and IDH-wt tumors had the poorest overall survival (OS) of 11.3 months. Likewise, Labuissère [24] found that the presence of a TERTp mutation was an independent factor of poor prognosis (OS = 13.8 vs. 18.4 months), in both $I D H$-mut (OS = 13.8 vs. 37.6 months, $p=0.022$ ) and $I D H$-wt glioblastomas (OS $=13.7$ vs. 17.5 months, $p=0.006$ ). Simon et al. [72] further suggested that not only was the presence of a TERTp mutation a significant negative predictor of OS but that TERTp mutations were prognostically relevant in patients with residual tumors who did not receive temozolomide chemotherapy, suggesting that surgery and temozolomide chemotherapy combined (in contrast to surgery plus radiotherapy) was effective against tumor cells responsible for the potentially adverse prognosis associated with TERTp mutations.

On the contrary, a large multivariable genomic analysis of 1122 gliomas among which 590 glioblastomas [53] failed to observe a statistically significant and independent survival association with the presence of a TERTp mutation after accounting for age and grade. Likewise, Pegmezi et al. [76] found that the presence of TERTp mutations was not independently associated with OS in an analysis of 1206 among which 360 were glioblastomas. Eckel Passow et al. [17] in a study of 1087 gliomas among which 472 glioblastomas found that in gliomas, TERTp mutations are generally unfavorable in the absence of IDH mutation and favorable in the presence of IDH mutation and $1 \mathrm{p} / 19 \mathrm{q}$ codeletion.

Arita [14] analyzed the association between TERTp, IDH mutations, and MGMTp methylation status. MGMTp methylation is a well-established favorable prognostic factor for glioblastoma and is a predictive factor of response for elderly patients [66,77]. TERTp mutation was a favorable prognostic factor in IDH-mut glioblastoma, whereas it was an unfavorable prognostic factor in IDH-wt glioblastoma. TERTp mutation status appeared to depend not only on the IDH mutation status but also on the MGMTp methylation status in a combined cohort of 453 IDH-wt glioblastoma samples, where patients carrying TERTp mutations and unmethylated MGMTp had the poorest prognosis.

The overall survival results of the main studies are presented in Table 2. The prognostic role of TERTp mutations has not been clearly established since there are numerous confusing factors both clinical such as age, initial surgical procedure, and molecular such as IDH mutations, MGMT methylation status, or EGFR amplification. Prospective studies on large cohorts with a homogeneous patient population (for example glioblastoma IDH-wt 
and MGMTp-unmethymated) are still necessary to assess the independent prognostic impact of the TERTp mutation.

Table 2. Prognostic impact of TERTp mutations in glioblastoma.

\begin{tabular}{|c|c|c|c|}
\hline $\begin{array}{c}\text { Population } \\
\text { (Number of Patients) }\end{array}$ & $\begin{array}{l}\text { TERTp-mut vs. TERTp-wt Glioblastoma } \\
\text { (Median Overall Survival, Months) }\end{array}$ & Independent Factor? & Reference \\
\hline $453 \mathrm{IDH}$-wt glioblastomas & 14.6 vs. 18.8 & $\begin{array}{c}\text { Uncertain } \\
\text { Confounding factor with } \\
\text { MGMTp methylation }\end{array}$ & [14] \\
\hline $303 \mathrm{IDH}$-wt glioblastomas & 18.5 vs. $17.8, p=0.3845$ & No & {$[64]$} \\
\hline $\begin{array}{c}358 \text { glioblastomas (322 [89.9\%] } \\
\text { IDH-wt) }\end{array}$ & 9.6 vs. $9.3, p=0.22$ & $\begin{array}{c}\text { No } \\
\text { Association with } I D H \\
\text { mutation }\end{array}$ & [75] \\
\hline $395 I D H$-wt glioblastomas & 13.7 vs. $17.5, p=0.006$ & $\begin{array}{c}\text { Uncertain } \\
\text { Confounding factor with } \\
E G F R \text { amplification }\end{array}$ & [24] \\
\hline $178 \mathrm{IDH}$-wt glioblastomas & 11 vs. $16, p=0.038$ & $\begin{array}{l}\text { Uncertain } \\
\text { Association with tumor } \\
\text { resection and exposition to } \\
\text { temozolomide }\end{array}$ & [72] \\
\hline $\begin{array}{l}243 \text { IDH-unknown } \\
\text { glioblastomas }\end{array}$ & 10 vs. $21, p<0.001$ & $\begin{array}{c}\text { Uncertain } \\
\text { No stratification on IDH } \\
\text { statusAssociation with TERT } \\
\text { polymorphism rs2853669 }\end{array}$ & [73] \\
\hline
\end{tabular}

\subsubsection{Pediatric Glioblastoma}

Brain tumors are the most common solid tumors in children and the leading cause of morbidity and mortality. Pediatric high-grade gliomas (pHGG) represent approximately 8 to $12 \%$ of pediatric brain tumors with a reported age-adjusted incidence of 0.26 per 100,000 population $[78,79]$. They mainly include diffuse astrocytic tumors, anaplastic astrocytoma, and glioblastoma $[78,80]$. They may manifest across all ages and anatomic CNS compartments [81]. Though phenotypically similar to adult glioblastoma, molecular profiling studies suggest a different biology in the pathogenesis of adult and pediatric high-grade gliomas [82,83].

Several pathways and molecular alterations were identified including the PI3K/AKT, Ras-Raf-MEK-ERK, RB, and p53 pathways as well as histone modifications [84]. In 2012, the first genome-wide sequencing among pediatric high-grade gliomas study identified a high frequency of alterations associated with histone modifications [85]. More specifically, mutations in the histone 3.1 and 3.3 proteins, encoded by the HIST1H3B and H3F3A genes, respectively. These alterations in the H3.3-ATRX-DAXX chromatin-remodeling pathway are present in $44 \%$ of glioblastomas and found to be specific to glioblastoma and highly prevalent in children and young adults. Subsequently, further studies have confirmed histone modifications as a hallmark of high-grade gliomas in children and young adults $[81,83,86,87]$.

Mutations on H3.3 at G34 define a molecular subgroup of pHGG associating loss of function mutations in the tumor suppressor protein 53 (TP53) and mutations in ATRX or DAXX. ATRX and DAXX are components of a chromatin remodeling complex necessary for the incorporation of histone $\mathrm{H} 3.3$ at the pericentric heterochromatin of telomeres. ATRX inactivation is, therefore, necessary to result in telomerase-independent maintenance through ALT. This mechanism allows glioma cells to extend their telomeres without TERT expression and represents a way to avoid apoptosis thus enabling cancer progression [88]. BRAF (v-raf murine sarcoma viral oncogene homolog B1 gene/protein) Raf kinase-activating mutations occur in 5 to $10 \%$ of pHGGs, mutation BRAF V600E being the most commonly 
observed and associated with a significantly improved prognosis. NTRK fusion has also been described and reported in approximately $10 \%$ of non-brainstem pHGG and up to $40 \%$ of infants younger than three years. Mutations concerning either BRAF or NTRK fusions are of particular interest since they represent potentially targetable alterations. Data concerning inhibition has been encouraging in BRAF V600E mutant gliomas [89] as well as entrectinib in NTRK-fusion positive pHGG [90].

Data concerning TERTp mutations in pediatric glioblastoma are scarce. TERTp mutations were reported at a much lower rate in pediatric glioblastoma ranging from 3 to $11 \%[7,10,91]$ suggesting that infinite proliferation of cancer cells is generally not achieved by TERTp mutation-meditated activation of telomerase. Instead, they frequently display a loss of $A T R X$ and an alternative lengthening of telomeres phenotype that maintains or increases telomere length $[55,85]$. Concerning the largest cohort of pHGG including midline pontine glioma, TERTp mutations were identified in 5/326 cases (1.5\%). TERTp mutations were not associated with a histone mutation. Alternative lengthening of telomeres was mutually exclusive of TERTp mutations and present among $19.2 \%$ of only 26 analyzed samples [84].

Other mechanisms have also been reported such as methylation of the TERTp [92]. TERTp methylation located in a specific area-UTSS (upstream of the transcription start site) - was found to be a biomarker that can differentiate normal tissues and low-grade tumors from TERT expressing high-grade neoplasms. UTSS hypermethylation was associated with tumor progression and poor prognosis. Malignant tumors that did not have UTSS hypermethylation did not express TERT and had an ALT phenotype. In a study among 50 high-grade glioma samples [93], high TERC (telomerase RNA template) and $h T E R T$ expression were found in a majority of both brainstem and diffuse intrinsic pontine glioma. In multivariable analyses, increased TERC and $h T E R T$ levels were associated with worse prognosis in patients with non-brainstem high-grade gliomas, after controlling for tumor grade or resection extent. However, the prognostic relevance of TERT associated alterations in pediatric glioblastomas remains understudied.

TERTp alterations are very rare in pHGG compared to adult glioblastoma. Their association with histone alterations or IDH mutations as well as their clinical impact are still unresolved questions.

\subsubsection{Rare Tumors Subtypes}

Glioblastoma IDH-wt does not constitute a homogeneous entity [94] and rare subtypes were described and included in a 2016 WHO classification [9]: gliosarcoma, giant cell glioblastoma, and epithelioid glioblastoma.

Gliosarcoma accounts for around $2 \%$ of glioblastomas and is composed of both a sarcomatous and glial component. Gliosarcoma patients are predominantly middle-aged men with a tumor frequently located in the temporal lobes. Its clinical particularity is its propensity to develop extracranial metastasis, which has been reported in up to $11 \%$ of patients [95]. Treatment of gliosarcoma encompasses the same approach as regular primary glioblastoma. It has been traditionally associated with poor prognosis but its prognostic significance still remains uncertain. As far as genetic alterations are concerned, common genetic alterations have been found in both sarcomatous and glial components suggesting a monoclonal origin $[95,96]$. Gliosarcoma is characterized by the absence of IDH1/2 mutations, TERTp mutations in over $80 \%$ of cases, frequent TP53 mutations, and absence of ATRX mutations and EGFR amplifications [97-99]. In a series of 36 gliosarcomas [97], TERTp mutations were reported in $88 \%$ of gliosarcoma and, when present, expressed in both the sarcomatous and glial components in $95 \%$ of cases. Overall, the mutations observed in gliosarcoma, apart from the absence of EGFR amplifications, are typical of "classical" IDH-wt glioblastoma (i.e., without the sarcomatous component).

Giant cell glioblastoma accounts for 1-5\% of glioblastoma and is characterized by the presence of multinucleated giant cells with abundant eosinophilic cytoplasm. It occurs more frequently in younger adults around 45 years $[97,100,101]$. Giant cell glioblastoma 
survival is superior to that observed with glioblastoma especially with some patients experiencing longer survival. Indeed, a five-year survival rate of more than $10 \%$ has been described [100]. Consequently, it has been suggested that genetic differences may contribute to the improved survival of patients. Giant cell glioblastomas are characterized by the absence of IDH1/2 mutations, high incidence of TP53 mutations (80-90\%), and PTEN mutations, frequent $A T R X$ mutations, and rare EGFR amplifications. Data concerning TERTp mutations are scarce but mutations have been reported in $25-40 \%$ of cases $[97,102]$. Interestingly, microsatellite instability was reported in $30 \%$ of patients in two series of 12 [101] and 14 [102] giant cell glioblastomas suggesting that patients harboring those tumors may benefit from the use of immunotherapy.

Epithelioid glioblastoma is one of the most rare subtypes and was recently included in the last WHO Classification [9]. It occurs frequently in the first three decades of life and is distinguished histologically by epithelioid cells with abundant cytoplasm, prominent nucleoli, and rhabdoid cells [103]. Epithelioid glioblastomas have a very specific genetic background with an absence of EGFR amplification, IDH1 gene mutations, or PTEN deletion, but instead, about half of them harbor BRAF V600E mutations [104,105]. TERTp mutations have not been described in the published series but a co-occurrence of $B R A F$ V600E and TERTp mutation has been reported in a case report [106]. A recent study highlighted that epitheloid glioblastoma could be separated into three distinct subgroups based on their alterations and clinical profiles: $I D H$-wt glioblastoma-like tumors, anaplastic pleomorphic xanthoastrocytoma, and RTK1 pediatric glioblastoma-like tumors [107].

Recently a new entity has emerged: diffuse astrocytic glioma, $I D H$-wt, with molecular features of glioblastoma, also called molecular glioblastoma. This entity appears with immunohistochemistry and/or iconographic features as a diffuse or anaplastic astrocytoma but the presence of specific molecular alterations (IDH1/2 wildtype, EGFR amplification, whole chromosome 7 gain/whole chromosome 10 loss, and mutation of TERTp) reclassify the lesion as a grade IV glioma [38]. No difference in survival was demonstrated between patients carrying this IDHwt WHO grade IV astrocytoma and "classical" IDHwt glioblastoma: median OS 23.8 months vs. 19.2 months, $p=0.242$ [108]. However, the optimal therapeutic strategy for these patients remains to be established in therapeutic trials dedicated to this population.

\subsection{Therapeutic Implications and Perspectives}

Considering the high frequency of TERTp mutation across glioblastoma and the fact that normal cells have lower telomerase activity than cancer cells, telomerase-inhibiting therapies appear to be an attractive target. However, due to the physiopathology of shortening telomeres, such a strategy is expected to be efficacious after multiple cell cycles in the presence of TERT inhibition. Currently, such targeted therapies are not approved in cancer care. Different approaches to target TERT activity, such as small molecule inhibitors, immunotherapy, and vaccines, are under investigation. Bajaj et al. [109] recently issued a review that encompasses biochemistry prerequisites for targeting telomerase, advantages, and challenges as well as actual and future development of telomerase inhibitors in solid tumors in general.

Regarding other usual chemotherapies, a preclinical study showed that eribulin, a microtubule inhibitor frequently prescribed in metastatic breast cancer, inhibited the growth of TERTp-mutated glioblastoma cell lines and significantly prolonged the survival of mice harboring brain tumors [110]. Eribulin has been described as a microtubule inhibitor but has also been shown to have specific inhibitory activity against a TERT-RNA-dependent RNA polymerase (RdRP) [111]. RdRP is described as one of the non-canonical functions of TERT and is involved in M-phase progression through the promotion of heterochromatin assembly and the maintenance of the stem-cell property.

Imetelstat is a small TERT inhibitor that has shown promising results in the treatment of essential thrombocytopenia, a chronic myeloproliferative neoplasm. Imetelstat was investigated for its ability to target early megakaryocyte progenitors and cancer stem cells 
because these cells have higher telomerase activity and shorter telomere lengths [112]. In glioblastoma cell lines [113], long-term imetelstat treatment led to progressive telomere shortening, reduced proliferation rates, and induced cell death in glioblastoma tumorinitiating cells. Imetelstat in combination with radiation and temozolomide had a dramatic effect on cell survival and activated the DNA damage response pathway. However, a clinical trial testing imetelstat in pediatric refractory CNS tumors was prematurely halted due to the death of two patients due to intratumoral hemorrhage secondary to treatmentrelated thrombocytopenia [114]. Further clinical trials are ongoing for both solid and hematological neoplasms in adults and younger patients. Pediatric tumors of interest include brain tumors, lymphomas, and refractory solid tumors. In adults, imetelstat is currently under investigation for myeloma, lymphoma, myelofibrosis as non-small-cell lung cancer, and breast cancer.

Mutations in the TERTp region result in an ETS site recognized by GABPA, a component of the multimeric transcription factor GABP, which facilitates reactivation of telomerase. The GABP transcription factor is an obligate multimer consisting of the DNA-binding $\mathrm{GABP} \alpha$ subunit and trans-activating GABP $\beta$ subunit. GABP $\beta 1 \mathrm{~L}$ is a tetramer-forming $\beta 1 \mathrm{~L}$ isoform of GABP that has been deemed necessary to activate the mutant TERT promoter in cells. Targeting GABP $\beta 1 \mathrm{~L}$ rather than TERT itself may represent a way to target TERTpmutated cells while sparing normal cells to avoid the hematopoietic side effects observed with imetelstat. In glioblastoma cell lines, it was shown that disruption of the $\beta 1 \mathrm{~L}$ isoform of GABP reverses the replicative immortality of TERTp-mutated glioblastoma cells [115]. In a mouse xenograft model of glioblastoma, knocking down GABP $\beta 1 \mathrm{~L}$ impaired tumor growth and increased mouse survival.

Preclinical data suggest that BIBR1532, a potent telomerase inhibitor, can induce apoptosis by downregulating telomerase activity at the transcriptional and translational levels [116,117]. However, to date, there are no available clinical data or ongoing clinical trials investigating BIBR1532.

Other strategies rely on the development of telomerase-targeted immunotherapy among which are TERT activity-targeted vaccines. Such an approach requires the identification of a tumor-associated antigen. An ideal tumor-associated antigen should have the following characteristics: a selective and broad expression in cancer cells, within all phases of tumor progression and the capacity to induce strong and effective immune responses. $h T E R T$ has been identified as such a tumor-associated antigen $[118,119]$. Dendritic cells (DC) represent a heterogeneous family of immune cells that link innate and adaptive immunity. They represent the most potent antigen-presenting cells in the human immune system and therefore constitute an effective tool to induce potent antitumor immune responses. In a phase I/II trial on seven glioblastoma patients [120], DCs transfected with RNA purified from autologous cancer stem cell cultures in combination with $h T E R T$ and mRNA were administered after the completion of standard post-operative chemo-radiotherapy. All treated subjects developed an immune response without significant toxicity or signs of autoimmunity. Vaccinated patients had significantly longer PFS compared to the historicalmatched controls (694 days vs. 236 days, $p=0.0018$ ) and $5 / 7$ patients were alive after a two-year follow-up.

More recently, a phase II clinical trial [121] evaluated a cell vaccine (DCV) pulsed with glioblastoma stem-like cell antigens. Forty-three recurrent $(n=19)$ or primary $(n=24)$ glioblastoma patients were randomized at a 1:1 ratio after surgery to receive either DCV or placebo. Patients were stratified based on the mutational status of IDH1/2 and TERTp. DCV did not significantly improve OS or PFS in all 43 patients. After adjusting for TERTp and IDH1/2 mutational status, and B7-H4 expression, the DCV improved OS ( $p=0.02$; HR 2.5; 95\% [CI] 1.15-5.45) but not PFS. B7 molecules are important mediators of immune evasion in the tumor microenvironment, among which B7-H4 is highly expressed in high-grade gliomas [122]. B7-H4 activation in the microenvironment of gliomas has been identified as an important immunosuppressive event blocking effective T-cell immune responses [123]. Interestingly, the IDH1-wt TERTp-mut glioblastoma subtype exhibited lower expression of 
B7-H4 compared with the other two groups, which could explain why IDH1-wt TERTpmut glioblastoma patients showed a more important clinical benefit from DCV treatment. Glioblastoma patients presenting with TERTp mutated tumors may therefore constitute preferential candidates for DCV treatment.

$\mathrm{UCPVax}$ is a therapeutic anti-cancer vaccine based on telomerase-derived helper peptides designed to induce strong Th1 CD4 T cell responses [124]. This vaccine was reported to be safe in phase I trials though results have yet to be published. Phase II trials are ongoing in metastatic NSCLC both in monotherapy (NCT02818426) and in combination with nivolumab (NCT04263051). A phase I/II trial in adult patients suffering from glioblastoma is also ongoing (NCT04280848).

Considering the multiple pathways leading to telomerase activation, telomeraseinhibiting strategies offer the possibility to explore therapeutic strategies as diverse as vaccines, immunotherapies, and the reconsideration of standard chemotherapies. Physiopathological consequences of TERTp mutations and potential druggable targets are shown in Figure 3.

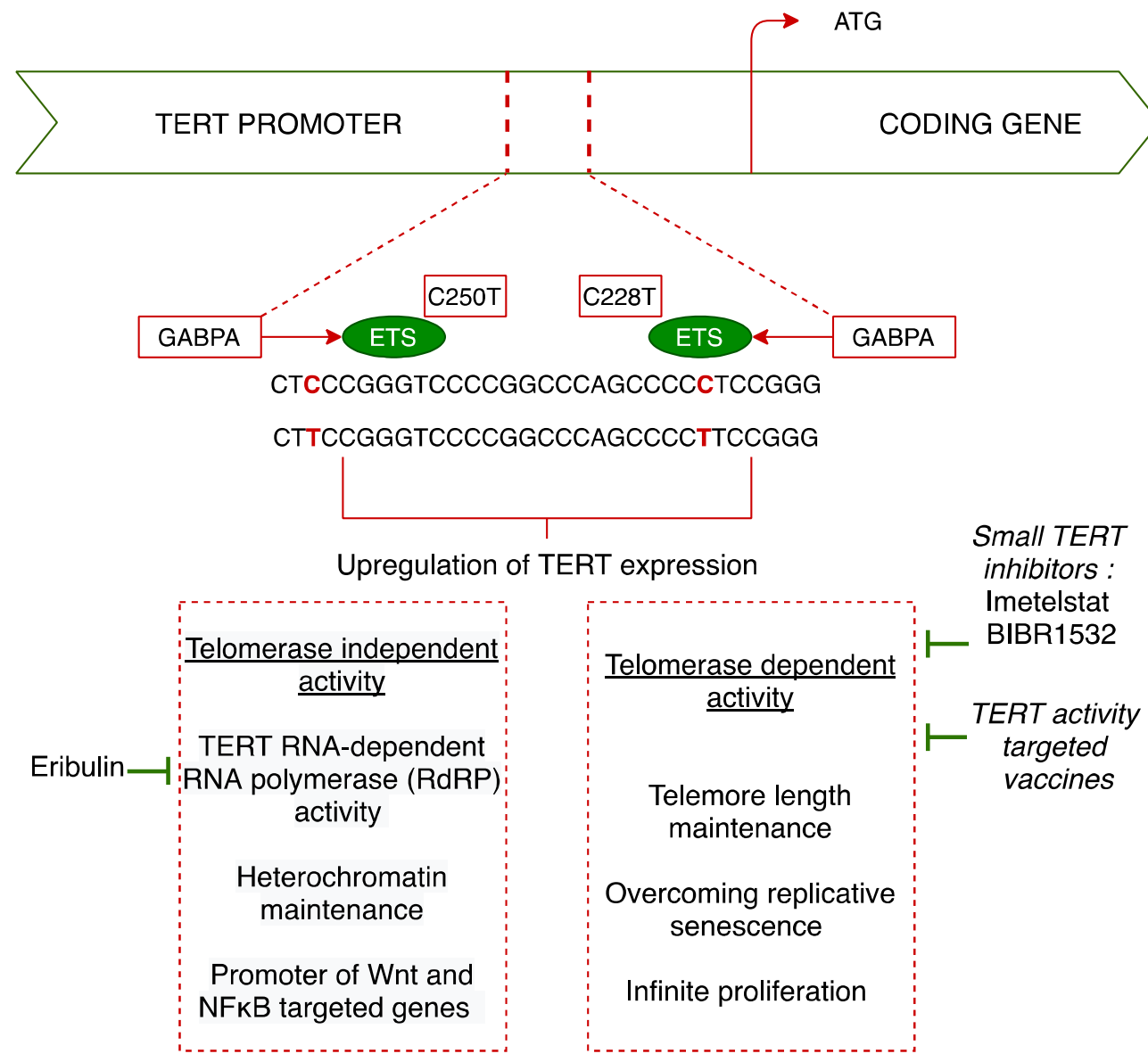

Figure 3. Physiopathological consequences of TERTp alterations in glioblastoma and therapeutic perspectives.

To date, there are no validated and efficient glioblastoma treatments regarding TERTp mutations.

\section{Conclusions}

Telomere maintenance mechanisms during DNA replication are essential across glioblastomas. TERTp mutations are the most represented alterations in glioblastoma, suggesting a pivotal role in oncogenesis. The identification of TERTp mutations is essential and is currently integrated into glioblastoma diagnostic procedures. Despite data from 
multiple sources, the prognostic impact of TERTp mutations remains controversial. A better understanding of the molecular mechanisms underlying TERTp-mutated glioblastoma could lead to the development of TERT-targeted therapies. Preclinical and clinical trials are ongoing, but no such therapy has yet demonstrated clinical efficiency in glioblastoma patient care.

Author Contributions: Conceptualization, M.F. and N.O.; methodology, N.O.; validation, M.F.; formal analysis, N.O.; investigation, N.O. and M.F.; writing-original draft preparation, N.O.; writing-review and editing, M.F., V.G., F.M., F.C. and F.D.F.; visualization, M.F; and F.M.; supervision, M.F., F.C. and F.D.F.; project administration, M.F. All authors have read and agreed to the published version of the manuscript.

Funding: This research received no external funding.

Institutional Review Board Statement: Not applicable.

Informed Consent Statement: Not applicable.

Data Availability Statement: Not applicable.

Conflicts of Interest: The authors declare no conflict of interest related to the present review.

$\begin{array}{ll}\text { Abbreviations } \\ \text { ALT } & \text { Alternative Lengthening of Telomeres } \\ \text { ATRX } & \alpha \text {-thalassemia/mental retardation syndrome X-linked } \\ \text { ctDNA } & \text { Circulating Tumor Deoxyribonucleic Acid } \\ \text { CNS } & \text { Central Nervous System } \\ \text { CSF } & \text { CerebroSpinal Fluid } \\ \text { DAXX } & \text { Death-associated protein 6 } \\ \text { ddPCR } & \text { Droplet digital Polymerase Chain Reaction } \\ \text { DC } & \text { Dentritic Cells } \\ \text { DCE-MRI } & \text { Dynamic Contrast Enhanced-Magnetic Resonance Imaging } \\ \text { DNA } & \text { Deoxyribonucleic Acid } \\ \text { EGFR } & \text { Epidermal Growth Factor Receptor } \\ \text { Erbb2 } & \text { v-erb-b2 avian erythroblastic leukemia viral oncogene homolog } 2 \\ \text { ETS } & \text { E26 transformation-specific family transcription factor } \\ \text { IDH } & \text { Isocitrate Dehydrogenase } \\ \text { IDH-wt } & \text { Isocitrate Dehydrogenase-wild-type } \\ \text { IDH-mut } & \text { Isocitrate Dehydrogenase-mutated } \\ \text { hTERT } & \text { Human Telomerase Reverse Transcriptase } \\ \text { NGS } & \text { New Generation Sequencing } \\ \text { MGMT } & \text { O6-methylguanine-DNA methyltransferase } \\ \text { MRI } & \text { Magnetic Resonance Imaging } \\ \text { NOS } & \text { Not Otherwise Specified } \\ \text { OS } & \text { Overall Survival } \\ \text { pHGG } & \text { Pediatric High Grade Gliomas } \\ \text { PI3KR1 } & \text { Phosphatidylinositol 3-kinase regulatory subunit alpha } \\ \text { RNA } & \text { Ribonucleic Acid } \\ \text { RdRP } & \text { RNA-dependent RNA polymerase } \\ \text { TCGA } & \text { The Cancer Genome Atlas } \\ \text { TERC } & \text { Telomerase RNA template } \\ \text { TERTp } & \text { TElomerase Reverse Transcriptase Promoter } \\ \text { TERTp-mut } & \text { TElomerase Reverse Transcriptase Promoter mutated } \\ \text { TERTp-wt } & \text { TElomerase Reverse Transcriptase Promoter wild-type } \\ \text { TP53 } & \text { Tumor suppressor Protein 53 } \\ \text { UTSS } & \text { Upstream of the Transcription Start Site } \\ & \end{array}$




\section{References}

1. Lapointe, S.; Perry, A.; Butowski, N.A. Primary Brain Tumours in Adults. Lancet 2018, 392, 432-446. [CrossRef]

2. Ostrom, Q.T.; Gittleman, H.; Liao, P.; Vecchione-Koval, T.; Wolinsky, Y.; Kruchko, C.; Barnholtz-Sloan, J.S. CBTRUS Statistical Report: Primary Brain and Other Central Nervous System Tumors Diagnosed in the United States in 2010-2014. Neuro-oncology 2017, 19, v1-v88. [CrossRef]

3. Stupp, R.; Brada, M.; van den Bent, M.J.; Tonn, J.-C.; Pentheroudakis, G.; On behalf of the ESMO Guidelines Working Group. HighGrade Glioma: ESMO Clinical Practice Guidelines for Diagnosis, Treatment and Follow-Up. Ann. Oncol. 2014, 25, iii93-iii101. [CrossRef]

4. Wen, P.Y.; Kesari, S. Malignant Gliomas in Adults. N. Engl. J. Med. 2008, 359, 492-507. [CrossRef] [PubMed]

5. Bergo, E.; Lombardi, G.; Guglieri, I.; Capovilla, E.; Pambuku, A.; Zagone, V. Neurocognitive Functions and Health-Related Quality of Life in Glioblastoma Patients: A Concise Review of the Literature. Eur. J. Cancer Care 2019, 28, e12410. [CrossRef]

6. The Cancer Genome Atlas Research Network. Comprehensive Genomic Characterization Defines Human Glioblastoma Genes and Core Pathways. Nature 2008, 455, 1061-1068. [CrossRef]

7. Brennan, C.W.; Verhaak, R.G.W.; McKenna, A.; Campos, B.; Noushmehr, H.; Salama, S.R.; Zheng, S.; Chakravarty, D.; Sanborn, J.Z.; Berman, S.H.; et al. The Somatic Genomic Landscape of Glioblastoma. Cell 2013, 155, 462-477. [CrossRef]

8. Parsons, D.W.; Jones, S.; Zhang, X.; Lin, J.C.-H.; Leary, R.J.; Angenendt, P.; Mankoo, P.; Carter, H.; Siu, I.-M.; Gallia, G.L.; et al. An Integrated Genomic Analysis of Human Glioblastoma Multiforme. Science 2008, 321, 1807-1812. [CrossRef]

9. Louis, D.N.; Perry, A.; Reifenberger, G.; von Deimling, A.; Figarella-Branger, D.; Cavenee, W.K.; Ohgaki, H.; Wiestler, O.D.; Kleihues, P.; Ellison, D.W. The 2016 World Health Organization Classification of Tumors of the Central Nervous System: A Summary. Acta Neuropathol. 2016, 131, 803-820. [CrossRef]

10. Killela, P.J.; Reitman, Z.J.; Jiao, Y.; Bettegowda, C.; Agrawal, N.; Diaz, L.A.; Friedman, A.H.; Friedman, H.; Gallia, G.L.; Giovanella, B.C.; et al. TERT Promoter Mutations Occur Frequently in Gliomas and a Subset of Tumors Derived from Cells with Low Rates of Self-Renewal. Proc. Natl. Acad. Sci. USA 2013, 110, 6021-6026. [CrossRef] [PubMed]

11. Kim, N.; Piatyszek, M.; Prowse, K.; Harley, C.; West, M.; Ho, P.; Coviello, G.; Wright, W.; Weinrich, S.; Shay, J. Specific Association of Human Telomerase Activity with Immortal Cells and Cancer. Science 1994, 266, 2011-2015. [CrossRef]

12. Horn, S.; Figl, A.; Rachakonda, P.S.; Fischer, C.; Sucker, A.; Gast, A.; Kadel, S.; Moll, I.; Nagore, E.; Hemminki, K.; et al. TERT Promoter Mutations in Familial and Sporadic Melanoma. Science 2013, 339, 959-961. [CrossRef]

13. Huang, F.W.; Hodis, E.; Xu, M.J.; Kryukov, G.V.; Chin, L.; Garraway, L.A. Highly Recurrent TERT Promoter Mutations in Human Melanoma. Science 2013, 339, 957-959. [CrossRef] [PubMed]

14. Arita, H.; Yamasaki, K.; Matsushita, Y.; Nakamura, T.; Shimokawa, A.; Takami, H.; Tanaka, S.; Mukasa, A.; Shirahata, M.; Shimizu, S.; et al. A Combination of TERT Promoter Mutation and MGMT Methylation Status Predicts Clinically Relevant Subgroups of Newly Diagnosed Glioblastomas. Acta Neuropathol. Commun. 2016, 4, 79. [CrossRef] [PubMed]

15. Meyerson, M.; Counter, C.M.; Eaton, E.N.; Ellisen, L.W.; Steiner, P.; Caddle, S.D.; Ziaugra, L.; Beijersbergen, R.L.; Davidoff, M.J.; Liu, Q.; et al. HEST2, the Putative Human Telomerase Catalytic Subunit Gene, Is Up-Regulated in Tumor Cells and during Immortalization. Cell 1997, 90, 785-795. [CrossRef]

16. Barthel, F.P.; Wei, W.; Tang, M.; Martinez-Ledesma, E.; Hu, X.; Amin, S.B.; Akdemir, K.C.; Seth, S.; Song, X.; Wang, Q.; et al. Systematic Analysis of Telomere Length and Somatic Alterations in 31 Cancer Types. Nat. Genet. 2017, 49, 349-357. [CrossRef]

17. Eckel-Passow, J.E.; Lachance, D.H.; Molinaro, A.M.; Walsh, K.M.; Decker, P.A.; Sicotte, H.; Pekmezci, M.; Rice, T.; Kosel, M.L.; Smirnov, I.V.; et al. Glioma Groups Based on 1p/19q, IDH, and TERT Promoter Mutations in Tumors. N. Engl. J. Med. 2015, 372, 2499-2508. [CrossRef]

18. Mosrati, M.A.; Malmström, A.; Lysiak, M.; Krysztofiak, A.; Hallbeck, M.; Milos, P.; Hallbeck, A.-L.; Bratthäll, C.; Strandéus, M.; Stenmark-Askmalm, M.; et al. TERT Promoter Mutations and Polymorphisms as Prognostic Factors in Primary Glioblastoma. Oncotarget 2015, 6, 16663-16673. [CrossRef]

19. Yuan, Y.; Qi, C.; Maling, G.; Xiang, W.; Yanhui, L.; Ruofei, L.; Yunhe, M.; Jiewen, L.; Qing, M. TERT Mutation in Glioma: Frequency, Prognosis and Risk. J. Clin. Neurosci. 2016, 26, 57-62. [CrossRef]

20. Spiegl-Kreinecker, S.; Lötsch, D.; Ghanim, B.; Pirker, C.; Mohr, T.; Laaber, M.; Weis, S.; Olschowski, A.; Webersinke, G.; Pichler, J.; et al. Prognostic Quality of Activating TERT Promoter Mutations in Glioblastoma: Interaction with the Rs2853669 Polymorphism and Patient Age at Diagnosis. Neuro-oncology 2015, 17, 1231-1240. [CrossRef]

21. Kim, H.S.; Kwon, M.J.; Song, J.H.; Kim, E.S.; Kim, H.Y.; Min, K.-W. Clinical Implications of TERT Promoter Mutation on IDH Mutation and MGMT Promoter Methylation in Diffuse Gliomas. Pathol. Res. Pract. 2018, 214, 881-888. [CrossRef]

22. Fan, X.; Wang, Y.; Liu, Y.; Liu, X.; Zhang, C.; Wang, L.; Li, S.; Ma, J.; Jiang, T. Brain Regions Associated with Telomerase Reverse Transcriptase Promoter Mutations in Primary Glioblastomas. J. Neurooncol. 2016, 128, 455-462. [CrossRef] [PubMed]

23. Pierini, T.; Nardelli, C.; Lema Fernandez, A.G.; Pierini, V.; Pellanera, F.; Nofrini, V.; Gorello, P.; Moretti, M.; Arniani, S.; Roti, G.; et al. New Somatic TERT Promoter Variants Enhance the Telomerase Activity in Glioblastoma. Acta Neuropathol. Commun. 2020, 8, 145. [CrossRef]

24. Labussiere, M.; Boisselier, B.; Mokhtari, K.; Di Stefano, A.-L.; Rahimian, A.; Rossetto, M.; Ciccarino, P.; Saulnier, O.; Paterra, R.; Marie, Y.; et al. Combined Analysis of TERT, EGFR, and IDH Status Defines Distinct Prognostic Glioblastoma Classes. Neurology 2014, 83, 1200-1206. [CrossRef] [PubMed] 
25. Sasaki, T.; Fukai, J.; Kodama, Y.; Hirose, T.; Okita, Y.; Moriuchi, S.; Nonaka, M.; Tsuyuguchi, N.; Terakawa, Y.; Uda, T.; et al. Characteristics and Outcomes of Elderly Patients with Diffuse Gliomas: A Multi-Institutional Cohort Study by Kansai Molecular Diagnosis Network for CNS Tumors. J. Neurooncol. 2018, 140, 329-339. [CrossRef] [PubMed]

26. Vinagre, J.; Almeida, A.; Pópulo, H.; Batista, R.; Lyra, J.; Pinto, V.; Coelho, R.; Celestino, R.; Prazeres, H.; Lima, L.; et al. Frequency of TERT Promoter Mutations in Human Cancers. Nat. Commun. 2013, 4, 2185. [CrossRef]

27. You, H.; Wu, Y.; Chang, K.; Shi, X.; Chen, X.-D.; Yan, W.; Li, R. Paradoxical Prognostic Impact of TERT Promoter Mutations in Gliomas Depends on Different Histological and Genetic Backgrounds. CNS Neurosci. 2017, 23, 790-797. [CrossRef] [PubMed]

28. Pesenti, C.; Paganini, L.; Fontana, L.; Veniani, E.; Runza, L.; Ferrero, S.; Bosari, S.; Menghi, M.; Marfia, G.; Caroli, M.; et al. Mass Spectrometry-Based Assay for the Molecular Diagnosis of Glioma: Concomitant Detection of Chromosome 1p/19q Codeletion, and IDH1, IDH2, and TERT Mutation Status. Oncotarget 2017, 8, 57134-57148. [CrossRef] [PubMed]

29. Diplas, B.H.; Liu, H.; Yang, R.; Hansen, L.J.; Zachem, A.L.; Zhao, F.; Bigner, D.D.; McLendon, R.E.; Jiao, Y.; He, Y.; et al. Sensitive and Rapid Detection of TERT Promoter and IDH Mutations in Diffuse Gliomas. Neuro-oncology 2019, 21, 440-450. [CrossRef] [PubMed]

30. Ge, J.; Liu, M.Y.; Li, L.; Deng, Q.; Liu, F.; Luo, Y.; Wang, L.; Yao, G.; Zhu, D.; Lu, H.; et al. Detection of IDH1 and TERT Promoter Mutations with Droplet Digital PCR in Diffuse Gliomas. Int. J. Clin. Exp. Pathol. 2020, 13, 230-238.

31. Fontanilles, M.; Marguet, F.; Beaussire, L.; Magne, N.; Pépin, L.-F.; Alexandru, C.; Tennevet, I.; Hanzen, C.; Langlois, O.; Jardin, F.; et al. Cell-Free DNA and Circulating TERT Promoter Mutation for Disease Monitoring in Newly-Diagnosed Glioblastoma. Acta Neuropathol. Commun. 2020, 8, 179. [CrossRef]

32. Nikiforova, M.N.; Wald, A.I.; Melan, M.A.; Roy, S.; Zhong, S.; Hamilton, R.L.; Lieberman, F.S.; Drappatz, J.; Amankulor, N.M.; Pollack, I.F.; et al. Targeted Next-Generation Sequencing Panel (GlioSeq) Provides Comprehensive Genetic Profiling of Central Nervous System Tumors. Neuro-oncology 2016, 18, 379-387. [CrossRef]

33. Higa, N.; Akahane, T.; Yokoyama, S.; Yonezawa, H.; Uchida, H.; Takajo, T.; Kirishima, M.; Hamada, T.; Matsuo, K.; Fujio, S.; et al. A Tailored Next-generation Sequencing Panel Identified Distinct Subtypes of Wildtype IDH and TERT Promoter Glioblastomas. Cancer Sci. 2020, 111, 3902. [CrossRef] [PubMed]

34. Sahm, F.; Schrimpf, D.; Jones, D.T.W.; Meyer, J.; Kratz, A.; Reuss, D.; Capper, D.; Koelsche, C.; Korshunov, A.; Wiestler, B.; et al. Next-Generation Sequencing in Routine Brain Tumor Diagnostics Enables an Integrated Diagnosis and Identifies Actionable Targets. Acta Neuropathol. 2016, 131, 903-910. [CrossRef] [PubMed]

35. Synhaeve, N.E.; van den Bent, M.J.; French, P.J.; Dinjens, W.N.M.; Atmodimedjo, P.N.; Kros, J.M.; Verdijk, R.; Dirven, C.M.F.; Dubbink, H.J. Clinical Evaluation of a Dedicated next Generation Sequencing Panel for Routine Glioma Diagnostics. Acta Neuropathol. Commun. 2018, 6, 126. [CrossRef]

36. Zacher, A.; Kaulich, K.; Stepanow, S.; Wolter, M.; Köhrer, K.; Felsberg, J.; Malzkorn, B.; Reifenberger, G. Molecular Diagnostics of Gliomas Using Next Generation Sequencing of a Glioma-Tailored Gene Panel: Next Generation Molecular Diagnostics of Gliomas. Brain Pathol. 2017, 27, 146-159. [CrossRef] [PubMed]

37. Euskirchen, P.; Bielle, F.; Labreche, K.; Kloosterman, W.P.; Rosenberg, S.; Daniau, M.; Schmitt, C.; Masliah-Planchon, J.; Bourdeaut, F.; Dehais, C.; et al. Same-Day Genomic and Epigenomic Diagnosis of Brain Tumors Using Real-Time Nanopore Sequencing. Acta Neuropathol. 2017, 134, 691-703. [CrossRef]

38. Brat, D.J.; Aldape, K.; Colman, H.; Holland, E.C.; Louis, D.N.; Jenkins, R.B.; Kleinschmidt-DeMasters, B.K.; Perry, A.; Reifenberger, G.; Stupp, R.; et al. CIMPACT-NOW Update 3: Recommended Diagnostic Criteria for “Diffuse Astrocytic Glioma, IDH-Wildtype, with Molecular Features of Glioblastoma, WHO Grade IV. " Acta Neuropathol. 2018, 136, 805-810. [CrossRef]

39. Barritault, M.; Picart, T.; Poncet, D.; Fenouil, T.; d’Hombres, A.; Gabut, M.; Guyotat, J.; Jouanneau, E.; Ameli, R.; Joubert, B.; et al. Avoiding New Biopsies by Identification of IDH1 and TERT Promoter Mutation in Nondiagnostic Biopsies From Glioma Patients. Neurosurgery 2020. [CrossRef]

40. Yamashita, K.; Hatae, R.; Hiwatashi, A.; Togao, O.; Kikuchi, K.; Momosaka, D.; Yamashita, Y.; Kuga, D.; Hata, N.; Yoshimoto, K.; et al. Predicting TERT Promoter Mutation Using MR Images in Patients with Wild-Type IDH1 Glioblastoma. Diagn. Interv. Imaging 2019, 100, 411-419. [CrossRef]

41. Ozturk-Isik, E.; Cengiz, S.; Ozcan, A.; Yakicier, C.; Ersen Danyeli, A.; Pamir, M.N.; Özduman, K.; Dincer, A. Identification of IDH and TERTp Mutation Status Using ${ }^{1}$ H-MRS in 112 Hemispheric Diffuse Gliomas. J. Magn Reson Imaging 2020, 51, 1799-1809. [CrossRef] [PubMed]

42. Zhang, H.; lyu, G.; He, W.; Lei, Y.; Lin, F.; Wang, M.; Zhang, H.; Liang, L.; Feng, Y.; Yang, J. DSC and DCE Histogram Analyses of Glioma Biomarkers, Including IDH, MGMT, and TERT, on Differentiation and Survival. Acad. Radiol. 2020. [CrossRef] [PubMed]

43. Deniel, A.; Marguet, F.; Beaussire, L.; Tobenas-Dujardin, A.-C.; Peillon, C.; Gambirasio, M.-A.; Veresezan, O.; Magne, N.; Di Fiore, F.; Laquerrière, A.; et al. TERTp Mutation Detection in Plasma by Droplet-Digital Polymerase Chain Reaction in Spinal Myxopapillary Ependymoma with Lung Metastases. World Neurosurg. 2019, 130, 405-409. [CrossRef] [PubMed]

44. Juratli, T.A.; Stasik, S.; Zolal, A.; Schuster, C.; Richter, S.; Daubner, D.; Juratli, M.A.; Thowe, R.; Hennig, S.; Makina, M.; et al. TERT Promoter Mutation Detection in Cell-Free Tumor-Derived DNA in Patients with IDH Wild-Type Glioblastomas: A Pilot Prospective Study. Clin. Cancer Res. 2018, 24, 5282-5291. [CrossRef]

45. Mouliere, F.; Chandrananda, D.; Piskorz, A.M.; Moore, E.K.; Morris, J.; Ahlborn, L.B.; Mair, R.; Goranova, T.; Marass, F.; Heider, K.; et al. Enhanced Detection of Circulating Tumor DNA by Fragment Size Analysis. Sci. Transl. Med. 2018, 10, eaat4921. [CrossRef] [PubMed] 
46. Ersoy, T.F.; Keil, V.C.; Hadizadeh, D.R.; Gielen, G.H.; Fimmers, R.; Waha, A.; Heidenreich, B.; Kumar, R.; Schild, H.H.; Simon, M. New Prognostic Factor Telomerase Reverse Transcriptase Promotor Mutation Presents without MR Imaging Biomarkers in Primary Glioblastoma. Neuroradiology 2017, 59, 1223-1231. [CrossRef]

47. Tian, H.; Wu, H.; Wu, G.; Xu, G. Noninvasive Prediction of TERT Promoter Mutations in High-Grade Glioma by Radiomics Analysis Based on Multiparameter MRI. BioMed Res. Int. 2020, 2020, 3872314. [CrossRef]

48. Ivanidze, J.; Lum, M.; Pisapia, D.; Magge, R.; Ramakrishna, R.; Kovanlikaya, I.; Fine, H.A.; Chiang, G.C. MRI Features Associated with TERT Promoter Mutation Status in Glioblastoma. J. Neuroimaging 2019, 29, 357-363. [CrossRef]

49. de Lange, T. How Telomeres Solve the End-Protection Problem. Science 2009, 326, 948-952. [CrossRef]

50. Masutomi, K.; Hahn, W.C. Telomerase and Tumorigenesis. Cancer Lett. 2003, 194, 163-172. [CrossRef]

51. Arita, H.; Narita, Y.; Fukushima, S.; Tateishi, K.; Matsushita, Y.; Yoshida, A.; Miyakita, Y.; Ohno, M.; Collins, V.P.; Kawahara, N.; et al. Upregulating Mutations in the TERT Promoter Commonly Occur in Adult Malignant Gliomas and Are Strongly Associated with Total 1p19q Loss. Acta Neuropathol. 2013, 126, 267-276. [CrossRef] [PubMed]

52. Bell, R.J.A.; Rube, H.T.; Kreig, A.; Mancini, A.; Fouse, S.D.; Nagarajan, R.P.; Choi, S.; Hong, C.; He, D.; Pekmezci, M.; et al. The Transcription Factor GABP Selectively Binds and Activates the Mutant TERT Promoter in Cancer. Science 2015, 348, 1036-1039. [CrossRef] [PubMed]

53. Ceccarelli, M.; Barthel, F.P.; Malta, T.M.; Sabedot, T.S.; Salama, S.R.; Murray, B.A.; Morozova, O.; Newton, Y.; Radenbaugh, A.; Pagnotta, S.M.; et al. Molecular Profiling Reveals Biologically Discrete Subsets and Pathways of Progression in Diffuse Glioma. Cell 2016, 164, 550-563. [CrossRef] [PubMed]

54. Law, M.J.; Lower, K.M.; Voon, H.P.J.; Hughes, J.R.; Garrick, D.; Viprakasit, V.; Mitson, M.; De Gobbi, M.; Marra, M.; Morris, A.; et al. ATR-X Syndrome Protein Targets Tandem Repeats and Influences Allele-Specific Expression in a Size-Dependent Manner. Cell 2010, 143, 367-378. [CrossRef] [PubMed]

55. Heaphy, C.M.; de Wilde, R.F.; Jiao, Y.; Klein, A.P.; Edil, B.H.; Shi, C.; Bettegowda, C.; Rodriguez, F.J.; Eberhart, C.G.; Hebbar, S.; et al. Altered Telomeres in Tumors with ATRX and DAXX Mutations. Science 2011, 333, 425. [CrossRef] [PubMed]

56. Heidenreich, B.; Rachakonda, P.S.; Hosen, I.; Volz, F.; Hemminki, K.; Weyerbrock, A.; Kumar, R. TERT Promoter Mutations and Telomere Length in Adult Malignant Gliomas and Recurrences. Oncotarget 2015, 6, 10617-10633. [CrossRef]

57. Abou-El-Ardat, K.; Seifert, M.; Becker, K.; Eisenreich, S.; Lehmann, M.; Hackmann, K.; Rump, A.; Meijer, G.; Carvalho, B.; Temme, A.; et al. Comprehensive Molecular Characterization of Multifocal Glioblastoma Proves Its Monoclonal Origin and Reveals Novel Insights into Clonal Evolution and Heterogeneity of Glioblastomas. Neuro-oncology 2017, 19, 546-557. [CrossRef]

58. Lee, J.H.; Lee, J.E.; Kahng, J.Y.; Kim, S.H.; Park, J.S.; Yoon, S.J.; Um, J.-Y.; Kim, W.K.; Lee, J.-K.; Park, J.; et al. Human Glioblastoma Arises from Subventricular Zone Cells with Low-Level Driver Mutations. Nature 2018, 560, 243-247. [CrossRef] [PubMed]

59. Körber, V.; Yang, J.; Barah, P.; Wu, Y.; Stichel, D.; Gu, Z.; Fletcher, M.N.C.; Jones, D.; Hentschel, B.; Lamszus, K.; et al. Evolutionary Trajectories of IDHWT Glioblastomas Reveal a Common Path of Early Tumorigenesis Instigated Years Ahead of Initial Diagnosis. Cancer Cell 2019, 35, 692-704. [CrossRef]

60. Yan, H.; Parsons, D.W.; Jin, G.; McLendon, R.; Rasheed, B.A.; Yuan, W.; Kos, I.; Batinic-Haberle, I.; Jones, S.; Riggins, G.J.; et al. IDH1 and IDH2 Mutations in Gliomas. N. Engl. J. Med. 2009, 360, 765-773. [CrossRef]

61. Lee, Y.; Koh, J.; Kim, S.-I.; Won, J.K.; Park, C.-K.; Choi, S.H.; Park, S.-H. The Frequency and Prognostic Effect of TERT Promoter Mutation in Diffuse Gliomas. Acta Neuropathol. Commun. 2017, 5, 62. [CrossRef]

62. Killela, P.J.; Pirozzi, C.J.; Healy, P.; Reitman, Z.J.; Lipp, E.; Rasheed, B.A.; Yang, R.; Diplas, B.H.; Wang, Z.; Greer, P.K.; et al. Mutations in IDH1, IDH2, and in the TERT Promoter Define Clinically Distinct Subgroups of Adult Malignant Gliomas. Oncotarget 2014, 5, 1515-1525. [CrossRef] [PubMed]

63. Brito, C.; Azevedo, A.; Esteves, S.; Marques, A.R.; Martins, C.; Costa, I.; Mafra, M.; Bravo Marques, J.M.; Roque, L.; Pojo, M. Clinical Insights Gained by Refining the 2016 WHO Classification of Diffuse Gliomas with: EGFR Amplification, TERT Mutations, PTEN Deletion and MGMT Methylation. BMC Cancer 2019, 19, 968. [CrossRef] [PubMed]

64. Nguyen, H.N.; Lie, A.; Li, T.; Chowdhury, R.; Liu, F.; Ozer, B.; Wei, B.; Green, R.M.; Ellingson, B.M.; Wang, H.; et al. Human TERT Promoter Mutation Enables Survival Advantage from MGMT Promoter Methylation in IDH1 Wild-Type Primary Glioblastoma Treated by Standard Chemoradiotherapy. Neuonc 2016, now189. [CrossRef] [PubMed]

65. Shu, C.; Wang, Q.; Yan, X.; Wang, J. The TERT Promoter Mutation Status and MGMT Promoter Methylation Status, Combined with Dichotomized MRI-Derived and Clinical Features, Predict Adult Primary Glioblastoma Survival. Cancer Med. 2018, 7, 3704-3712. [CrossRef] [PubMed]

66. Hegi, M.E.; Diserens, A.-C.; Gorlia, T.; Hamou, M.-F.; de Tribolet, N.; Weller, M.; Kros, J.M.; Hainfellner, J.A.; Mason, W.; Mariani, L.; et al. MGMT Gene Silencing and Benefit from Temozolomide in Glioblastoma. N. Engl. J. Med. 2005, 352, 997-1003. [CrossRef] [PubMed]

67. Yang, P.; Cai, J.; Yan, W.; Zhang, W.; Wang, Y.; Chen, B.; Li, G.; Li, S.; Wu, C.; Yao, K.; et al. Classification Based on Mutations of TERT Promoter and IDH Characterizes Subtypes in Grade II/III Gliomas. Neuro-oncology 2016, 18, 1099-1108. [CrossRef] [PubMed]

68. Razis, E.; Kotoula, V.; Koliou, G.-A.; Papadopoulou, K.; Vrettou, E.; Giannoulatou, E.; Tikas, I.; Labropoulos, S.V.; Rigakos, G.; Papaemmanoyil, S.; et al. Is There an Independent Role of TERT and NF1 in High Grade Gliomas? Transl. Oncol. 2020, 13, 346-354. [CrossRef] 
69. Gao, K.; Li, G.; Qu, Y.; Wang, M.; Cui, B.; Ji, M.; Shi, B.; Hou, P. TERT Promoter Mutations and Long Telomere Length Predict Poor Survival and Radiotherapy Resistance in Gliomas. Oncotarget 2016, 7, 8712-8725. [CrossRef]

70. Geng, P.; Zhao, X.; Ou, J.; Li, J.; Sa, R.; Liang, H. TERT Genetic Mutations as Prognostic Marker in Glioma. Mol. Neurobiol. 2017, 54, 3665-3669. [CrossRef]

71. Chen, C.; Han, S.; Meng, L.; Li, Z.; Zhang, X.; Wu, A. TERT Promoter Mutations Lead to High Transcriptional Activity under Hypoxia and Temozolomide Treatment and Predict Poor Prognosis in Gliomas. PLoS ONE 2014, 9, e100297. [CrossRef]

72. Simon, M.; Hosen, I.; Gousias, K.; Rachakonda, S.; Heidenreich, B.; Gessi, M.; Schramm, J.; Hemminki, K.; Waha, A.; Kumar, R. TERT Promoter Mutations: A Novel Independent Prognostic Factor in Primary Glioblastomas. Neuro-oncology 2015, 17, 45-52. [CrossRef]

73. Batista, R.; Cruvinel-Carloni, A.; Vinagre, J.; Peixoto, J.; Catarino, T.A.; Campanella, N.C.; Menezes, W.; Becker, A.P.; de Almeida, G.C.; Matsushita, M.M.; et al. The Prognostic Impact of TERT Promoter Mutations in Glioblastomas Is Modified by the Rs2853669 Single Nucleotide Polymorphism: TERTP Mutations and SNP in GBM Survival. Int. J. Cancer 2016, 139, 414-423. [CrossRef] [PubMed]

74. Hewer, E.; Prebil, N.; Berezowska, S.; Gutt-Will, M.; Schucht, P.; Dettmer, M.S.; Vassella, E. Diagnostic Implications of TERT Promoter Mutation Status in Diffuse Gliomas in a Routine Clinical Setting. Virchows Arch. 2017, 471, 641-649. [CrossRef] [PubMed]

75. Nonoguchi, N.; Ohta, T.; Oh, J.-E.; Kim, Y.-H.; Kleihues, P.; Ohgaki, H. TERT Promoter Mutations in Primary and Secondary Glioblastomas. Acta Neuropathol. 2013, 126, 931-937. [CrossRef]

76. Pekmezci, M.; Rice, T.; Molinaro, A.M.; Walsh, K.M.; Decker, P.A.; Hansen, H.; Sicotte, H.; Kollmeyer, T.M.; McCoy, L.S.; Sarkar, G.; et al. Adult Infiltrating Gliomas with WHO 2016 Integrated Diagnosis: Additional Prognostic Roles of ATRX and TERT. Acta Neuropathol. 2017, 133, 1001-1016. [CrossRef]

77. Wick, W.; Hartmann, C.; Engel, C.; Stoffels, M.; Felsberg, J.; Stockhammer, F.; Sabel, M.C.; Koeppen, S.; Ketter, R.; Meyermann, R.; et al. NOA-04 Randomized Phase III Trial of Sequential Radiochemotherapy of Anaplastic Glioma With Procarbazine, Lomustine, and Vincristine or Temozolomide. J. Clin. Oncol. 2009, 27, 5874-5880. [CrossRef]

78. Sturm, D.; Pfister, S.M.; Jones, D.T.W. Pediatric Gliomas: Current Concepts on Diagnosis, Biology, and Clinical Management. JCO 2017, 35, 2370-2377. [CrossRef] [PubMed]

79. Haase, S.; Nuñez, F.M.; Gauss, J.C.; Thompson, S.; Brumley, E.; Lowenstein, P.; Castro, M.G. Hemispherical Pediatric High-Grade Glioma: Molecular Basis and Therapeutic Opportunities. IJMS 2020, 21, 9654. [CrossRef]

80. Blionas, A.; Giakoumettis, D.; Klonou, A.; Neromyliotis, E.; Karydakis, P.; Themistocleous, M.S. Paediatric Gliomas: Diagnosis, Molecular Biology and Management. Ann. Transl. Med. 2018, 6, 251. [CrossRef] [PubMed]

81. Salloum, R.; McConechy, M.K.; Mikael, L.G.; Fuller, C.; Drissi, R.; DeWire, M.; Nikbakht, H.; De Jay, N.; Yang, X.; Boue, D.; et al. Characterizing Temporal Genomic Heterogeneity in Pediatric High-Grade Gliomas. Acta Neuropathol. Commun. 2017, 5, 78. [CrossRef]

82. Paugh, B.S.; Qu, C.; Jones, C.; Liu, Z.; Adamowicz-Brice, M.; Zhang, J.; Bax, D.A.; Coyle, B.; Barrow, J.; Hargrave, D.; et al. Integrated Molecular Genetic Profiling of Pediatric High-Grade Gliomas Reveals Key Differences With the Adult Disease. JCO 2010, 28, 3061-3068. [CrossRef]

83. Wu, G.; Diaz, A.K.; Paugh, B.S.; Rankin, S.L.; Ju, B.; Li, Y.; Zhu, X.; Qu, C.; Chen, X.; Zhang, J.; et al. Jude Children's Research Hospital-Washington University Pediatric Cancer Genome Project The Genomic Landscape of Diffuse Intrinsic Pontine Glioma and Pediatric Non-Brainstem High-Grade Glioma. Nat. Genet. 2014, 46, 444-450. [CrossRef]

84. Mackay, A.; Burford, A.; Carvalho, D.; Izquierdo, E.; Fazal-Salom, J.; Taylor, K.R.; Bjerke, L.; Clarke, M.; Vinci, M.; Nandhabalan, M.; et al. Integrated Molecular Meta-Analysis of 1,000 Pediatric High-Grade and Diffuse Intrinsic Pontine Glioma. Cancer Cell 2017, 32, 520-537. [CrossRef] [PubMed]

85. Schwartzentruber, J.; Korshunov, A.; Liu, X.-Y.; Jones, D.T.W.; Pfaff, E.; Jacob, K.; Sturm, D.; Fontebasso, A.M.; Quang, D.-A.K.; Tönjes, M.; et al. Driver Mutations in Histone H3.3 and Chromatin Remodelling Genes in Paediatric Glioblastoma. Nature 2012, 482, 226-231. [CrossRef] [PubMed]

86. Wu, G.; Broniscer, A.; McEachron, T.A.; Lu, C.; Paugh, B.S.; Becksfort, J.; Qu, C.; Ding, L.; Huether, R.; Parker, M.; et al. Jude Children's Research Hospital-Washington University Pediatric Cancer Genome Project Somatic Histone H3 Alterations in Pediatric Diffuse Intrinsic Pontine Gliomas and Non-Brainstem Glioblastomas. Nat. Genet. 2012, 44, 251-253. [CrossRef] [PubMed]

87. Sturm, D.; Witt, H.; Hovestadt, V.; Khuong-Quang, D.-A.; Jones, D.T.W.; Konermann, C.; Pfaff, E.; Tönjes, M.; Sill, M.; Bender, S.; et al. Hotspot Mutations in H3F3A and IDH1 Define Distinct Epigenetic and Biological Subgroups of Glioblastoma. Cancer Cell 2012, 22, 425-437. [CrossRef] [PubMed]

88. Haase, S.; Garcia-Fabiani, M.B.; Carney, S.; Altshuler, D.; Núñez, F.J.; Méndez, F.M.; Núñez, F.; Lowenstein, P.R.; Castro, M.G. Mutant ATRX: Uncovering a New Therapeutic Target for Glioma. Expert Opin. Ther. Targets 2018, 22, 599-613. [CrossRef]

89. Kaley, T.; Touat, M.; Subbiah, V.; Hollebecque, A.; Rodon, J.; Lockhart, A.C.; Keedy, V.; Bielle, F.; Hofheinz, R.-D.; Joly, F.; et al. BRAF Inhibition in BRAF V600 -Mutant Gliomas: Results From the VE-BASKET Study. JCO 2018, 36, 3477-3484. [CrossRef]

90. Mayr, L.; Guntner, A.S.; Madlener, S.; Schmook, M.T.; Peyrl, A.; Azizi, A.A.; Dieckmann, K.; Reisinger, D.; Stepien, N.M.; Schramm, K.; et al. Cerebrospinal Fluid Penetration and Combination Therapy of Entrectinib for Disseminated ROS1/NTRK-Fusion Positive Pediatric High-Grade Glioma. JPM 2020, 10, 290. [CrossRef] [PubMed] 
91. Koelsche, C.; Sahm, F.; Capper, D.; Reuss, D.; Sturm, D.; Jones, D.T.W.; Kool, M.; Northcott, P.A.; Wiestler, B.; Böhmer, K.; et al. Distribution of TERT Promoter Mutations in Pediatric and Adult Tumors of the Nervous System. Acta Neuropathol. 2013, 126, 907-915. [CrossRef]

92. Castelo-Branco, P.; Choufani, S.; Mack, S.; Gallagher, D.; Zhang, C.; Lipman, T.; Zhukova, N.; Walker, E.J.; Martin, D.; Merino, D.; et al. Methylation of the TERT Promoter and Risk Stratification of Childhood Brain Tumours: An Integrative Genomic and Molecular Study. Lancet Oncol. 2013, 14, 534-542. [CrossRef]

93. Dorris, K.; Sobo, M.; Onar-Thomas, A.; Panditharatna, E.; Stevenson, C.B.; Gardner, S.L.; DeWire, M.D.; Pierson, C.R.; Olshefski, R.; Rempel, S.A.; et al. Prognostic Significance of Telomere Maintenance Mechanisms in Pediatric High-Grade Gliomas. J. Neurooncol. 2014, 117, 67-76. [CrossRef]

94. Chen, R.; Smith-Cohn, M.; Cohen, A.L.; Colman, H. Glioma Subclassifications and Their Clinical Significance. Neurotherapeutics 2017, 14, 284-297. [CrossRef]

95. Reis, R.M.; Könü-Lebleblicioglu, D.; Lopes, J.M.; Kleihues, P.; Ohgaki, H. Genetic Profile of Gliosarcomas. Am. J. Pathol. 2000, 156, 425-432. [CrossRef]

96. Actor, B.; Cobbers, J.M.J.L.; Büschges, R.; Wolter, M.; Knobbe, C.B.; Reifenberger, G.; Weber, R.G. Comprehensive Analysis of Genomic Alterations in Gliosarcoma and Its Two Tissue Components: Genomic Alterations in Gliosarcoma. Genes Chromosom. Cancer 2002, 34, 416-427. [CrossRef] [PubMed]

97. Oh, J.E.; Ohta, T.; Nonoguchi, N.; Satomi, K.; Capper, D.; Pierscianek, D.; Sure, U.; Vital, A.; Paulus, W.; Mittelbronn, M.; et al. Genetic Alterations in Gliosarcoma and Giant Cell Glioblastoma: Gliosarcoma and Giant Cell Glioblastoma. Brain Pathol. 2016, 26, 517-522. [CrossRef] [PubMed]

98. Lowder, L.; Hauenstein, J.; Woods, A.; Chen, H.-R.; Rupji, M.; Kowalski, J.; Olson, J.J.; Saxe, D.; Schniederjan, M.; Neill, S.; et al. Gliosarcoma: Distinct Molecular Pathways and Genomic Alterations Identified by DNA Copy Number/SNP Microarray Analysis. J. Neurooncol. 2019, 143, 381-392. [CrossRef]

99. Smith, D.R.; Wu, C.-C.; Saadatmand, H.J.; Isaacson, S.R.; Cheng, S.K.; Sisti, M.B.; Bruce, J.N.; Sheth, S.A.; Lassman, A.B.; Iwamoto, F.M.; et al. Clinical and Molecular Characteristics of Gliosarcoma and Modern Prognostic Significance Relative to Conventional Glioblastoma. J. Neurooncol. 2018, 137, 303-311. [CrossRef]

100. Kozak, K.R.; Moody, J.S. Giant Cell Glioblastoma: A Glioblastoma Subtype with Distinct Epidemiology and Superior Prognosis. Neuro-oncology 2009, 11, 833-841. [CrossRef]

101. Martinez, R.; Roggendorf, W.; Baretton, G.; Klein, R.; Toedt, G.; Lichter, P.; Schackert, G.; Joos, S. Cytogenetic and Molecular Genetic Analyses of Giant Cell Glioblastoma Multiforme Reveal Distinct Profiles in Giant Cell and Non-Giant Cell Subpopulations. Cancer Genet. Cytogenet. 2007, 175, 26-34. [CrossRef]

102. Cantero, D.; Mollejo, M.; Sepúlveda, J.M.; D’Haene, N.; Gutiérrez-Guamán, M.J.; Rodríguez de Lope, Á.; Fiaño, C.; Castresana, J.S.; Lebrun, L.; Rey, J.A.; et al. TP53, ATRX Alterations, and Low Tumor Mutation Load Feature IDH-Wildtype Giant Cell Glioblastoma despite Exceptional Ultra-Mutated Tumors. Neuro Oncol. Adv. 2020, 2, vdz059. [CrossRef] [PubMed]

103. Broniscer, A.; Tatevossian, R.G.; Sabin, N.D.; Klimo, P.; Dalton, J.; Lee, R.; Gajjar, A.; Ellison, D.W. Clinical, Radiological, Histological and Molecular Characteristics of Paediatric Epithelioid Glioblastoma: Epithelioid Glioblastoma in Children. Neuropathol. Appl. Neurobiol. 2014, 40, 327-336. [CrossRef] [PubMed]

104. Kleinschmidt-DeMasters, B.K.; Aisner, D.L.; Birks, D.K.; Foreman, N.K. Epithelioid GBMs Show a High Percentage of BRAF V600E Mutation: Am. J. Surg. Pathol. 2013, 37, 685-698. [CrossRef] [PubMed]

105. Alexandrescu, S.; Korshunov, A.; Lai, S.H.; Dabiri, S.; Patil, S.; Li, R.; Shih, C.-S.; Bonnin, J.M.; Baker, J.A.; Du, E.; et al. Epithelioid Glioblastomas and Anaplastic Epithelioid Pleomorphic Xanthoastrocytomas-Same Entity or First Cousins?: Epithelioid GBM and Anaplastic Epithelioid PXA. Brain Pathol. 2016, 26, 215-223. [CrossRef]

106. Matsumura, N.; Nakajima, N.; Yamazaki, T.; Nagano, T.; Kagoshima, K.; Nobusawa, S.; Ikota, H.; Yokoo, H. Concurrent TERT Promoter and BRAF V600E Mutation in Epithelioid Glioblastoma and Concomitant Low-Grade Astrocytoma: TERT Promoter and BRAF Mutation in E-GBM. Neuropathology 2017, 37, 58-63. [CrossRef]

107. Korshunov, A.; Chavez, L.; Sharma, T.; Ryzhova, M.; Schrimpf, D.; Stichel, D.; Capper, D.; Sturm, D.; Kool, M.; Habel, A.; et al. Epithelioid Glioblastomas Stratify into Established Diagnostic Subsets upon Integrated Molecular Analysis. Brain Pathol. 2018, 28, 656-662. [CrossRef]

108. Tesileanu, C.M.S.; Dirven, L.; Wijnenga, M.M.J.; Koekkoek, J.A.F.; Vincent, A.J.P.E.; Dubbink, H.J.; Atmodimedjo, P.N.; Kros, J.M.; van Duinen, S.G.; Smits, M.; et al. Survival of Diffuse Astrocytic Glioma, IDH1/2 Wildtype, with Molecular Features of Glioblastoma, WHO Grade IV: A Confirmation of the CIMPACT-NOW Criteria. Neuro-oncology 2020, 22, 515-523. [CrossRef]

109. Bajaj, S.; Kumar, M.S.; Peters, G.; Mayur, Y. Targeting Telomerase for Its Advent in Cancer Therapeutics. Med. Res. Rev. 2020, 40, 1871-1919. [CrossRef]

110. Takahashi, M.; Miki, S.; Fujimoto, K.; Fukuoka, K.; Matsushita, Y.; Maida, Y.; Yasukawa, M.; Hayashi, M.; Shinkyo, R.; Kikuchi, K.; et al. Eribulin Penetrates Brain Tumor Tissue and Prolongs Survival of Mice Harboring Intracerebral Glioblastoma Xenografts. Cancer Sci. 2019, 110, 2247-2257. [CrossRef]

111. Yamaguchi, S.; Maida, Y.; Yasukawa, M.; Kato, T.; Yoshida, M.; Masutomi, K. Eribulin Mesylate Targets Human Telomerase Reverse Transcriptase in Ovarian Cancer Cells. PLoS ONE 2014, 9, e112438. [CrossRef] 
112. Baerlocher, G.M.; Oppliger Leibundgut, E.; Ottmann, O.G.; Spitzer, G.; Odenike, O.; McDevitt, M.A.; Röth, A.; Daskalakis, M.; Burington, B.; Stuart, M.; et al. Telomerase Inhibitor Imetelstat in Patients with Essential Thrombocythemia. N. Engl. J. Med. 2015, 373, 920-928. [CrossRef]

113. Marian, C.O.; Cho, S.K.; Mcellin, B.M.; Maher, E.A.; Hatanpaa, K.J.; Madden, C.J.; Mickey, B.E.; Wright, W.E.; Shay, J.W.; Bachoo, R.M. The Telomerase Antagonist, Imetelstat, Efficiently Targets Glioblastoma Tumor-Initiating Cells Leading to Decreased Proliferation and Tumor Growth. Clin. Cancer Res. 2010, 16, 154-163. [CrossRef] [PubMed]

114. Salloum, R.; Hummel, T.R.; Kumar, S.S.; Dorris, K.; Li, S.; Lin, T.; Daryani, V.M.; Stewart, C.F.; Miles, L.; Poussaint, T.Y.; et al. A Molecular Biology and Phase II Study of Imetelstat (GRN163L) in Children with Recurrent or Refractory Central Nervous System Malignancies: A Pediatric Brain Tumor Consortium Study. J. Neurooncol. 2016, 129, 443-451. [CrossRef]

115. Mancini, A.; Xavier-Magalhães, A.; Woods, W.S.; Nguyen, K.-T.; Amen, A.M.; Hayes, J.L.; Fellmann, C.; Gapinske, M.; McKinney, A.M.; Hong, C.; et al. Disruption of the B1L Isoform of GABP Reverses Glioblastoma Replicative Immortality in a TERT Promoter Mutation-Dependent Manner. Cancer Cell 2018, 34, 513-528. [CrossRef] [PubMed]

116. Biray Avci, C.; Dogan, F.; Ozates Ay, N.P.; Goker Bagca, B.; Abbaszadeh, Z.; Gunduz, C. Effects of Telomerase Inhibitor on Epigenetic Chromatin Modification Enzymes in Malignancies. J. Cell Biochem. 2018, 119, 9817-9824. [CrossRef] [PubMed]

117. Lavanya, C.; Venkataswamy, M.M.; Sibin, M.K.; Srinivas Bharath, M.M.; Chetan, G.K. Down Regulation of Human Telomerase Reverse Transcriptase (HTERT) Expression by BIBR1532 in Human Glioblastoma LN18 Cells. Cytotechnology 2018, 70, 1143-1154. [CrossRef]

118. Negrini, S.; De Palma, R.; Filaci, G. Anti-Cancer Immunotherapies Targeting Telomerase. Cancers 2020, 12, 2260. [CrossRef] [PubMed]

119. Mizukoshi, E.; Kaneko, S. Telomerase-Targeted Cancer Immunotherapy. IJMS 2019, 20, 1823. [CrossRef]

120. Vik-Mo, E.O.; Nyakas, M.; Mikkelsen, B.V.; Moe, M.C.; Due-Tønnesen, P.; Suso, E.M.I.; Sæbøe-Larssen, S.; Sandberg, C.; Brinchmann, J.E.; Helseth, E.; et al. Therapeutic Vaccination against Autologous Cancer Stem Cells with MRNA-Transfected Dendritic Cells in Patients with Glioblastoma. Cancer Immunol. Immunother. 2013, 62, 1499-1509. [CrossRef] [PubMed]

121. Yao, Y.; Luo, F.; Tang, C.; Chen, D.; Qin, Z.; Hua, W.; Xu, M.; Zhong, P.; Yu, S.; Chen, D.; et al. Molecular Subgroups and B7-H4 Expression Levels Predict Responses to Dendritic Cell Vaccines in Glioblastoma: An Exploratory Randomized Phase II Clinical Trial. Cancer Immunol. Immunother. 2018, 67, 1777-1788. [CrossRef]

122. Yao, Y.; Wang, X.; Jin, K.; Zhu, J.; Wang, Y.; Xiong, S.; Mao, Y.; Zhou, L. B7-H4 Is Preferentially Expressed in Non-Dividing Brain Tumor Cells and in a Subset of Brain Tumor Stem-like Cells. J. Neurooncol. 2008, 89, 121-129. [CrossRef] [PubMed]

123. Yao, Y.; Ye, H.; Qi, Z.; Mo, L.; Yue, Q.; Baral, A.; Hoon, D.S.B.; Vera, J.C.; Heiss, J.D.; Chen, C.C.; et al. B7-H4(B7x)-Mediated Cross-Talk between Glioma-Initiating Cells and Macrophages via the IL6/JAK/STAT3 Pathway Lead to Poor Prognosis in Glioma Patients. Clin. Cancer Res. 2016, 22, 2778-2790. [CrossRef] [PubMed]

124. Adotévi, O.; Dosset, M.; Galaine, J.; Beziaud, L.; Godet, Y.; Borg, C. Targeting Antitumor CD4 Helper T Cells with Universal Tumor-Reactive Helper Peptides Derived from Telomerase for Cancer Vaccine. Hum. Vaccines Immunother. 2013, 9, $1073-1077$. [CrossRef] [PubMed] 